\title{
Disentangling how management affects biomass stock and productivity of tropical secondary forests fallows $\hbar$
}

\author{
Pieter C.J. Moonen ${ }^{\mathrm{a}, *}$, Bruno Verbist ${ }^{\mathrm{a}}$, Faustin Boyemba Bosela ${ }^{\mathrm{b}}$, Lindsey Norgrove ${ }^{\mathrm{c}}$, Stefaan Dondeyne ${ }^{\mathrm{d}}$, \\ Koenraad Van Meerbeek ${ }^{\mathrm{a}, \mathrm{e}, \mathrm{f}}$, Elizabeth Kearsley ${ }^{\mathrm{g}}$, Hans Verbeeck ${ }^{\mathrm{g}}$, Pieter Vermeir ${ }^{\mathrm{h}}$, Pascal Boeckx ${ }^{\mathrm{i}}$, Bart Muys ${ }^{\mathrm{a}}$ \\ a Division of Forest, Nature and Landscape, Department of Earth and Environmental Sciences, KU Leuven, Belgium \\ ${ }^{\mathrm{b}}$ Faculté des Sciences, Université de Kisangani, Congo \\ c School of Agricultural, Forest and Food Sciences, Bern University of Applied Sciences, Switzerland \\ d Division of Soil and Water, Department of Earth and Environmental Sciences, KU Leuven, Belgium \\ e Center for Biodiversity Dynamics in a Changing World (BIOCHANGE), Aarhus University, Ny Munkegade 114, 8000 Aarhus C, Denmark \\ ${ }^{f}$ Section for Ecoinformatics and Biodiversity, Department of Bioscience, Aarhus University, Ny Munkegade 114, 8000 Aarhus, C, Denmark \\ ${ }^{g}$ CAVElab - Computational and Applied Vegetation Ecology, Department of Applied Ecology and Environmental Biology, Ghent University, Belgium \\ h Laboratory of Chemical Analyses-LCA, Department of Green Chemistry and Technology, Ghent University, Belgium \\ i Isotope Bioscience Laboratory - ISOFYS, Ghent University, Belgium
}

\section{H I G H L I G H T S}

- Biomass in secondary forests of the Congo Basin declines with the number of slash and burn events.

- Repeated slash and burn events resulted in a shift in the structure and functional identity of the vegetation.

- Biomass productivity was best predicted by the functional identity of the vegetation.

- Biomass productivity was also predicted by the density of regenerating stems and soil fertility.

- Changes in functional identity most important pathway linking management to biomass productivity

\section{A R T I C L E I N F O}

\section{Article history:}

Received 14 June 2018

Received in revised form 8 December 2018

Accepted 9 December 2018

Available online 13 December 2018

Editor: Elena PAOLETTI

\section{Keywords:}

Slash and burn

Land use change

\section{G R A P H I C A L A B S T R A C T}

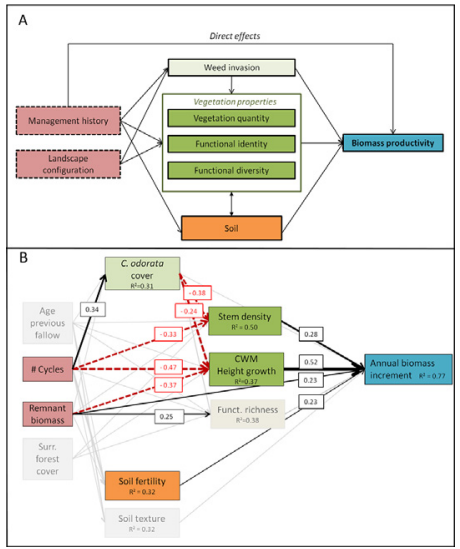

is Declarations of interest: none.

* Corresponding author at: Celestijnenlaan 200E B2411, 3001 Heverlee, Belgium.

E-mail address: moonen.pcj@gmail.com (P.C.J. Moonen). 
Ecosystem function

Soil carbon

Mass ratio effect

Complementarity effect fallow fields had, on average, 58.4 ( \pm 46.2 ) $\mathrm{Mg} \mathrm{ha}^{-1}$ AGB. AGB was positively related to both fallow age and to the proportion of remnant trees in AGB and negatively related to the number of previous cultivation cycles. Biomass productivity varied with the number of previous slash-and-burn cycles, with notable declines in the fourth cycle. The effect of management history was mainly through a reduction in the dominance of fast growing tree species and in the number of regenerating stems, which were also indirectly affected by an increase in $C$. odorata cover. Soil fertility status and the biomass of remnant trees also modified biomass productivity. Our findings suggest that under the current management intensity the capacity of the slash and burn system to provide important ecosystem functions, such as carbon sequestration, is declining.

(C) 2018 Elsevier B.V. All rights reserved.

\section{Introduction}

Secondary forests now constitute more than half of the world's tropical forests (FAO, 2015). They play an important role in global carbon, nitrogen and hydrological cycles (Bongers et al., 2015) and provide local communities with timber and non-timber forest products. In shifting cultivation systems, which cover an estimated 280 Mha worldwide (Heinimann et al., 2017), they are crucial in restoring soil fertility and maintaining livelihoods. Their capacity to deliver ecosystem services is determined by ecosystem functions comprising both rates of processes (e.g. fluxes of energy and materials) and size of compartments (e.g. pools of organic matter or carbon). Understanding how ecosystem functioning is affected by management is vital to predict impacts of future land use intensification and to design sustainable agroecosystems. Biomass production in fallows (secondary forest regrowth after slash and burn) strongly affects soil fertility restoration, weed suppression and wood production (Aweto, 2012, 1981; Szott et al., 1999; Wadsworth et al., 1990). The biomass productivity of tropical secondary fallows is determined by environmental conditions, i.e. climate (Poorter et al., 2016), soil conditions (Becknell and Powers, 2014, but see Lawrence et al., 2005), management history (Eaton and Lawrence, 2009; Jakovac et al., 2015; Lawrence et al., 2010; Styger et al., 2007, but see Wood et al., 2017) and landscape configuration (e.g. forest cover) (Norgrove and Beck, 2016). However, these drivers are not often assessed simultaneously and rarely explain the mechanisms and determinants leading to changes. Therefore, biomass productivity and succession remain highly unpredictable in strongly modified shifting cultivation landscapes (Arroyo-Rodriguez et al., 2017; Norden et al., 2015).

Ecosystem functioning is more directly determined by plant community composition, diversity and structure (Cardinale et al., 2012; Reiss et al., 2009). Currently, composition and diversity of plant functional traits are seen as the most direct link between biodiversity and ecosystem processes (Díaz et al., 2007). Plant functional traits are a range of plant characteristics that impact their performance in response to the environment and/or their effects on ecosystem functioning (Violle et al., 2007). For instance, the leaf economics spectrum is a set of plant traits which is related to their strategy in acquisition of resources with a trade-off between rapid growth and leaf persistence (Reich, 2014). Three hypotheses have been put forward to link vegetation properties, including functional traits, with ecosystem functions (Fig. 1). The niche complementarity hypothesis predicts a positive relationship between diversity in trait values (functional diversity) and ecosystem process rates (Mason et al., 2005). Greater diversity of functional trait values can influence ecosystem processes through complementary resource use (e.g. complete use of light through the presence of both light demanding and shade-tolerant species). The mass ratio hypothesis predicts that the trait values of the dominant species (functional identity) drive ecosystem processes, rather than the variation in trait values (Grime, 1998). For instance, a dominance of species with acquisitive trait values (e.g. high growth rate, low wood density) will be positively related to ecosystem process rates such as primary production. This dominance is detected through the community weighted mean (CWM) of traits. The vegetation quantity hypothesis proposes that the quality of the vegetation may not matter in ecosystem process rates, but simply the biomass (Finegan et al., 2015; Lohbeck et al., 2015).

There is increasing evidence of the role of vegetation properties (i.e. functional diversity, identity and vegetation structure) in affecting ecosystem process rates in tropical forest fallows after shifting cultivation. Aboveground biomass has been positively correlated with species and functional diversity (Bu et al., 2014), and with the CWM of specific leaf area (Lohbeck et al., 2015). Other studies found more limited effects of functional diversity: instead, initial vegetation biomass was found to be the main determinant of ecosystem process rates (Lohbeck et al., 2015; Prado-Junior et al., 2016), suggesting that vegetation quantity is more important than its functional identity or diversity.

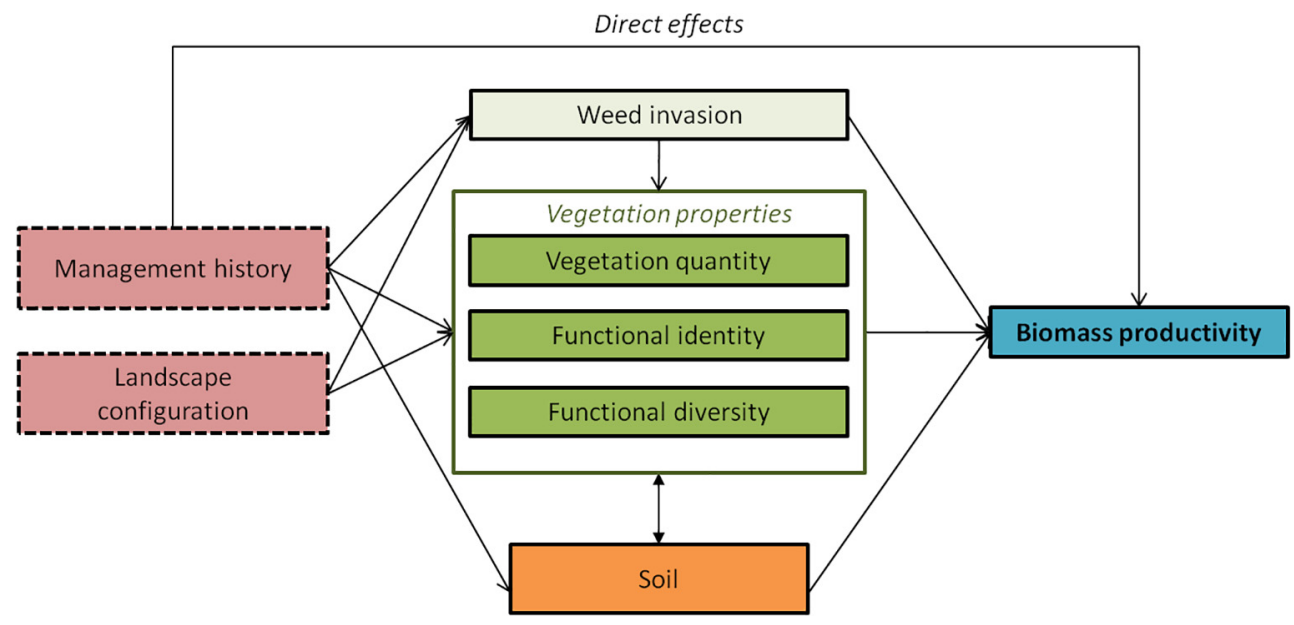

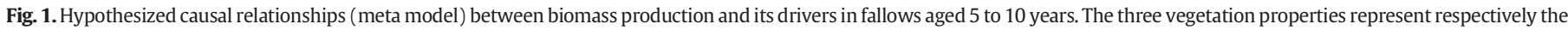

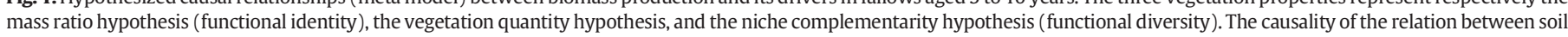
and vegetation properties (double headed arrow) was not assessed. 
Management history alters species composition and structure of fallows, with repeated cultivation filtering out seed-dependent species and favoring both strong sprouters and species that can cope with low nutrient availability (Jakovac et al., 2016; Robiglio and Sinclair, 2011). So changes in species composition associated with increasing management intensity need to be followed by changes in trait values related to more conservative and survival-focused strategies (Jakovac et al., 2016), but hardly any studies have explored this. An increasing number of shifting cultivation cycles has both been associated with an increase (due to increase in multistemmed resprouters, Jakovac et al., 2015) and a decrease (de Rouw, 1993; J. Tucker et al., 1998) in the number of stems and individuals, or no effect (e.g. Wood et al., 2017). The gradual invasion of weeds, in particular the asteraceous weed Chromolaena odorata (L.) R. M. King \& H. Rob, has been found to alter species composition and delay succession (de Foresta and Schwartz, 1991). The effect of old-growth forest in the landscape on vegetation properties is less clear than that of management intensity and may depend on fallow age: some studies found an effect on species composition (Robiglio and Sinclair, 2011), species diversity (Jakovac et al., 2015) and functional diversity (Norgrove and Beck, 2016), while species composition was found to be unaffected in young secondary forests (Jakovac et al., 2016; Reid et al., 2015). In Peru, the lack of an effect of number of previous cycles on biomass productivity was linked to the observation that fast growing pioneers were still present in the third cycle fallow (Wood et al., 2017), but this was not tested.

Thus, while there is evidence of the effect of management history on vegetation properties, and of the effect of vegetation properties on biomass productivity, the overall importance of the pathway in explaining biomass productivity in fallows has not been analyzed. Furthermore, its importance has not been compared to other pathways through which management history may affect fallow biomass productivity, such as soil fertility (Lawrence et al., 2007; Moran et al., 2000). In general, land use management, landscape configuration, vegetation properties and biomass regeneration are seldom linked in one causal network (Fig. 1).

Despite the importance of slash and burn systems in Central Africa (van Vliet et al., 2012), insights into the functioning of the system are scarce and its sustainability is still debated (Ickowitz et al., 2015; Moonen et al., 2016). There have been few studies from Africa on the impacts of shifting cultivation on secondary forest dynamics (Mukul and Herbohn, 2016). In the Democratic Republic of Congo (DRC), most forest clearing comprises the reuse of secondary forest and younger fallows or the clearing of forest edges (Molinario, 2017; Molinario et al., 2015; Potapov et al., 2012). Between 2000 and 2010 the extent of the agricultural land cover mosaic in DRC grew from 11.9 to $13.1 \%$ of its total land area (Molinario et al., 2015). Loss of secondary forest cover and associated gross aboveground carbon emissions were estimated to be respectively 2.3 and 1.4 times higher than losses due to primary forest cover loss (Tyukavina et al., 2013). However, changes in management intensity within the rural complex and its consequences on ecosystem functioning are not well known, nor are the net carbon outcomes of intended agricultural intensification programs (Ziegler et al., 2012).

We studied slash and burn systems in the humid forest zone of the Democratic Republic of the Congo (DRC), and how biomass and biomass regeneration in fallow fields following slash and burn are affected by vegetation properties, soil, landscape configuration and management history (Fig. 1). Our first objective was to relate aboveground biomass $\left(\mathrm{Mg} \mathrm{ha}^{-1}\right)$ in fallow fields to their age, management history, landscape configuration and soil characteristics. We hypothesized that aboveground biomass will increase with age and decline with increasing slash and burn cycles. Our second objective was to relate biomass productivity ( $\mathrm{Mg} \mathrm{ha}^{-1} \mathrm{yr}^{-1}$ ) in young fallow fields to management history and landscape configuration (Fig. 1) by asking three specific questions: (a) how do management history and landscape configuration affect vegetation quality, quantity and soil?; (b) What is the relative importance of vegetation quality, vegetation quantity and soil in explaining biomass productivity?; and (c) what is the relative importance of the different pathways linking management and landscape to biomass productivity? Based on (i) the vegetation quantity hypothesis, which predicts that the quantity of vegetation is more important than its quality in predicting productivity, and (ii) the mass ratio hypothesis, which predicts that the traits of the dominant species drive productivity, we hypothesized that biomass productivity will decline with increasing slash and burn cycles (i) predominantly due to a reduction in vegetation quantity and (ii) additionally due to a reduction in the dominance of acquisitive trait values (Fig. 1).

\section{Material and methods}

\subsection{Study site and description of shifting cultivation system}

This study was in Tshopo Province, central Congo basin in DRC. We sampled fallow fields in three villages (Yambela, Yaoseko and Bawi) (Table 1), located 52, 34 and $24 \mathrm{~km}$ from Kisangani. Natural vegetation is characterized by moist semi-deciduous rainforest and monodominant Gilbertiodendron dewevrei evergreen rainforest (Gilson et al., 1956). Following the Köppen-Geiger classification, the region has a tropical rainforest climate (Af) (Peel et al., 2007). Average annual precipitation is $1840 \mathrm{~mm}$ (as measured in Yangambi), with a dry season from December to February, during which average monthly precipitation does not exceed $100 \mathrm{~mm}$. Average temperatures are consistently high throughout the year, ranging from $24.2{ }^{\circ} \mathrm{C}$ in July to $25.5^{\circ} \mathrm{C}$ in March.

Yambela is on a plateau (up to $50 \mathrm{~m}$ altitudinal difference between plateau and valley bottoms) intersected by tributaries of the Congo and Lobaie rivers $\left(\mathrm{N} O 0^{\circ} 21^{\prime}\right.$; E24 ${ }^{\circ} 49^{\prime}$, mean plot altitude $470 \mathrm{~m}$ above sea level ( $\mathrm{m}$ asl)). Soils are excessively drained sandy to sandy-loam soils on the valley slopes, and well drained clayey-sandy and loamysandy soils on the plateau (Van Ranst et al., 2010) (Table A.1). Yaoseko is on a former river or lacustrine terrace next to the Congo river, shal-

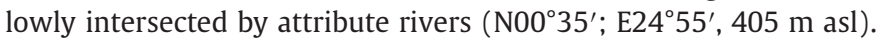
Both well-drained and temporary inundated soils are present, with sandy loam texture. Bawi is between the Lindi and Tshopo rivers. Here, both soils similar to the Yambela soils and soils richer in clay (developed on richer parent material) are represented ( $\mathrm{N}^{\circ} 0^{\circ} 42^{\prime} ; \mathrm{E} 25^{\circ} 11^{\prime}$, $420 \mathrm{~m}$ asl).

Agriculture is the main economic activity (Moonen et al., 2016). Main crops in the region typically comprise cassava, rice, plantain and maize, which are usually intercropped (Dowiya et al., 2009; Jalloh et al., 2012, Moonen, own observations). Soil and microclimate conditions vary among fields and depend partially on the number of previous cultivation cycles. Farmers typically clear 0.5 to 2 ha (Table 1 ) either in

Table 1

Descriptive statistics of the three study areas where fallow plots were located (Moonen, 2017).

\begin{tabular}{llll}
\hline & Yambela & Yaoseko & Bawi \\
\hline Population size & 646 & 3167 & 4660 \\
Population density (inhabitants $\left./ \mathrm{km}^{2}\right)^{\mathrm{a}}$ & 7 & 22 & 117 \\
Population density agriculture $\left(\text { inhabitants } / \mathrm{km}^{2}\right)^{\mathrm{a}}$ & 24 & 244 & 150 \\
Distance to Kisangani $(\mathrm{km})^{\mathrm{b}}$ & 52 & 34 & 24 \\
Mean distance to the old growth forest edge $(\mathrm{km})^{\mathrm{c}}$ & 2.5 & 4.5 & 7 \\
Ethnicity & Mbole & Turumbu & Manga \\
Mean fallow duration (yrs) & 4.3 & 5.2 & 4.4 \\
Median fallow duration (yrs) & 3.5 & 5 & 1.5 \\
Mean field size (ha) & 1.2 & 1.1 & 0.6
\end{tabular}

a Population density and population density agriculture refer respectively to the density of inhabitants calculated for the total village area (shifting cultivation area + primary forest); and for the shifting cultivation area only.

b The main market town in the region.

c Old growth forest is gradually cleared starting from the village center along the road to Kisangani. 
old growth forest or fallow land (secondary forests of differing ages) by slashing the understory vegetation, cutting trees and burning them. Fields are typically cultivated for two years. During the cropping phase and after field abandonment, vegetation recovers spontaneously with herbaceous and woody species establishing from seeds or resprouting from stumps. The fallow period is, depending on the length, a weed break and a soil fertility restoration phase. The age of fallow fields selected for cultivation varies according to household preferences and needs, but deviates from preferred ages due to increasing population densities (Table 1). In fields that have undergone more than three cultivation cycles volunteer oil palm (spontaneously established) is important, but slashing and burning continues. Deforestation (clearing of new fields in old-growth forest) follows a radiating pattern: with time, new fields are established further and further away from the villages. All three villages were established between 1925 and 1955, but differ in population densities and market accessibility (Table 1 ). As a result, especially in Bawi, land and resource use is more intense, and the remaining old growth forest within walking distance from the village center has been cut during the last decade.

\subsection{Forest inventory and functional traits}

We sampled 96 fallow fields of different age classes (0-5; 5-10;10$15 ; 15+$ years since abandonment) and land use history (number of previous cultivation cycles) in Yambela $(n=32)$, Yaoseko $(n=32)$ and Bawi $(\mathrm{n}=32$ ), located in agricultural landscapes of ca. 27, 13 and $31 \mathrm{~km}^{2}$. Data on 28 plots were collected in January-February of 2014, and on the remaining in January-April of 2015. The sampled plots were representative of the village agricultural practices, with the 32 sampled plots per village belonging to 25 different farmers in Bawi, 27 in Yambela and 24 in Yaoseko. We used stratified-random sampling, aiming to have a number of repetitions for each combination of age class and number of cycles.

Within each fallow, a $50 \times 50 \mathrm{~m}$ sample plot was established, in which we measured trees, shrubs and palms. The study had a 3-level nested sampling design to improve the efficiency of biomass estimations (Hairiah et al., 2011; Lawrence, 2005). As biomass is mostly in larger trees (Bastin et al., 2015), we limited the sample area of smaller trees, allowing more plots to be measured. Stems of trees and shrubs with $\mathrm{DBH} \geq 30 \mathrm{~cm}$ and palms were measured in the entire plot (totaling $2500 \mathrm{~m}^{2}$ ). Stems with DBH 5-30 cm were measured in 3 transects: two parallel transects of $5 \times 50 \mathrm{~m}$ and one transect of $5 \times 30 \mathrm{~m}$ connecting the two in the center of the plot (totaling $650 \mathrm{~m}^{2}$ ). Stems of woody regrowth with DBH 1-5 cm were measured in two subsections of the parallel transects totaling $50 \mathrm{~m}^{2}$. We determined whether stems were part of a multi-stemmed individual or not, sometimes by checking whether roots connected immediately under the soil surface. We estimated the cover (in \%) of: Chromolaena odorata, ferns and of other herbs in 5 parcels of $1 \mathrm{~m}^{2}$ whose fixed locations were spread out over the transect. We did not include non-woody biomass in biomass calculations, as we expected the woody biomass to make up the bulk of total biomass, increasingly so as fallow fields become older: in the "Alternatives to Slash and Burn" benchmark area in Cameroon, in fallow fields of 7 years, understory biomass (all biomass, including woody stems with $\mathrm{DBH}<2.5 \mathrm{~cm}$ ) made up on average $3 \%$ of all biomass with annual biomass increment as low as $0.2 \mathrm{Mg} \mathrm{ha}^{-1} \mathrm{yr}^{-1}$ (Nolte et al., 2001).

Measured stems were tagged and identified by botanists of the University of Kisangani (DR Congo) and local village experts. The DBH was recorded following the RAINFOR protocol, including methods for deviating points of measurement (Phillips et al., 2016). Specimens were taken for comparison with the reference collection of the herbarium of the Botanic Garden in Meise, Belgium. Tree heights were measured in each plot using a Vertex IV ultrasound system (Haglöf), with a random sample of half of all trees with $\mathrm{DBH}<30 \mathrm{~cm}$ measured and $85 \%$ of all trees with $\mathrm{DBH}>30$ measured. The top of the tree of tall trees $(\mathrm{H}$ $>30 \mathrm{~m}$ ) was determined from two different view angles.
Fallow fields often have remnants trees as farmers usually leave some trees standing when clearing vegetation prior to burning. These trees provide different functions during the cropping phase (e.g. shade, reducing soil temperatures), resources, (e.g. edible caterpillars, an important protein source, bark and leaves for medicinal purposes) or will be used for charcoal later (Okangola Ekeli, 2007). Remnant trees were defined as those that were not cut down during field preparation, and that survived until measurement. These can either comprise trees that originated in old-growth forests, secondary forests or a previous fallow phase. Two indicators were used to determine whether trees were remnants: (1) species identity, as some species are typical oldgrowth or old secondary forest species and (2) estimated tree increment rate, based on actual tree size in combination with fallow age. The plot owner and the team's botanist identified remnant trees. Afterwards, we performed a quality check to see if some remnant trees were not identified as such, by evaluating their mean annual increment (calculated using fallow age and DBH). Trees with a calculated annual increment of $>10 \mathrm{~cm} \mathrm{yr}^{-1}$ were considered remnants. Trees with a calculated annual increment of $>4 \mathrm{~cm} \mathrm{yr}^{-1}$, which were not pioneer species (defined as all species with $\mathrm{WD}<0.4 \mathrm{~g} \mathrm{~cm}^{-3}$ ), were also assumed to be remnant trees, as maximum increment potentials in (disturbed) central African moist forests range between 0.5 and $3.8 \mathrm{~cm} \mathrm{yr}^{-1}$ (Gourlet-fleury et al., 2011).

\subsection{Management and landscape attributes}

We gathered information on the management history of all plots by interviewing the owner using a structured questionnaire. This was used to determine: (i) the number of previous cultivation cycles (Cycles), (ii) the current fallow age (Age), (iii) the age of the former fallow when cut before the last cropping phase (Last age), (iv) the intensity of harvesting of fuel wood (Fuelwood), of construction wood (Construct) (both ordinal variables: none-medium-intense) and the number of trees harvested for making charcoal in the current fallow (Charcoal_C). Additionally we asked how many big trees the farmer left standing during last field preparation (Trees). To increase the accuracy of the recall data, the owner was interviewed at the edge of the plot. Responses were cross-checked by asking questions from different angles and sometimes by involving a family member. In the villages, fallows are grouped in a traditional classification system based upon the number of previous cultivation cycles, with four distinct classes. From 4 cycles onwards, they have the same name. In our analyses, the number of previous cultivation cycles was set to 4 for all plots that had undergone 4 or more cultivation cycles, as we had a limited number of plots having undergone 4 cycles. We refer to these as four + fallow fields. For first cycle fallow fields (first fallow after slashing old-growth forest), age of the last fallow was arbitrarily set to 30 years. The share of old-growth forest in the surrounding area ("surrounding forest cover" hereafter) was determined in a GIS analysis by drawing a $500 \mathrm{~m}$ radius buffer around the center of each plot, using an existing land cover map (FACET product (OSFAC, 2010), methodology described in Potapov et al., 2012).

\subsection{Quantification of vegetation quality and quantity}

We calculated community functional properties based on traits of species that contributed for at least $80 \%$ of the cumulative basal area in at least in one plot (Pakeman and Quested, 2007). This resulted in a list of 98 species, which represented, on average, $93 \%$ of the basal area of the plots. We selected six traits that represent species' resource acquisition strategies (pioneer species vs. shade-tolerant species and acquisitive vs. conservative strategies): wood density $\left(\mathrm{g} \mathrm{cm}^{-3}\right)$, max height $(\mathrm{m})$ and max height growth rate $\left(\mathrm{m} \mathrm{yr}^{-1}\right)$, specific leaf area (SLA, in $\mathrm{m}^{2} \mathrm{~kg}^{-1}$ ), leaf $\mathrm{N}$ content $\left(\mathrm{mg} \mathrm{g}^{-1}\right)$ and mean $\mathrm{DBH}$ growth rate $\left(\mathrm{cm} \mathrm{yr}^{-1}\right)$. Max height was determined as the 95th percentile of measured tree heights in our database. Max (95th percentile) height growth rate and mean $\mathrm{DBH}$ growth rate were calculated from own 
measurements of height and DBH and plot age, excluding remnant trees. For the other traits, two databases were used to obtain species trait values: (1) a database of traits measured in similar land use systems in the same region (at 10-100 km distance of our sites) (43 species, and 52 matching genus) (Kearsley et al., unpublished data; Kearsley et al., 2017) and (2) the global TRY database (remaining species) (Kattge et al., 2011). Because we relied on these databases some traits that might better reflect critical growth limiting factors as e.g. $\mathrm{N}$ : P ratio (Verbeeck et al., 2014) were not available. The traits were scaled to the community level by calculating functional identity indices (indicators for the mass ratio hypothesis) and functional diversity indices (FD, indicators for the niche complementarity hypothesis). Traits were weighted by species' relative basal area in the plot. Functional identity was calculated for each of the six traits as the average trait value in the community (community weighted mean) (Garnier et al., 2004). Functional diversity consists of multiple dimensions (Mason et al., 2005; Villéger et al., 2008). Therefore, three functional diversity indices were calculated. Functional richness is defined as the amount of niche space filled by species in the community, thus describing trait dissimilarity (hereafter FRic). Functional evenness is the evenness of abundance distribution in filled niche space (FEve). Functional dispersion is the mean distance in niche space of individual species to the centroid of all species (FDis) (Laliberte and Legendre, 2010). The three FD indices were calculated using species scores on the first three principal components of a standardized principal component analysis (PCA) executed on the six traits (these axes explained $79 \%$ of the variance in the data). All CWM and FD indices were calculated using the R-package "FD" (Laliberte et al., 2014).

Both basal area (Vilà et al., 2013) and biomass (Lohbeck et al., 2015) have been used as indicators for the vegetation quantity hypothesis (which proposes that biomass growth is mostly influenced by its quantity rather than its quality (functional identity and functional diversity). Here, we used stem density of woody stems $>5 \mathrm{~cm}$ diameter at breast height (DBH) and density of individuals (with at least one woody stem $>5 \mathrm{~cm}$ diameter at breast height (DBH) to capture this concept, as we did not have information on basal area or biomass.

\subsection{Soil characteristics}

We measured soil carbon and nitrogen content, soil texture and bulk density. We collected composite soil samples (mixed samples of 10 insertions per plot) at 4 depth intervals $(0-5,5-10,10-20,20-40 \mathrm{~cm})$. Carbon and nitrogen content were determined using a Carlo Erba 1110 Elemental Analyser (Ravindranath and Ostwald, 2008), based on the Dumas method. The particle size distribution of the air-dried soil fractions $(<2 \mathrm{~mm})$ was measured by the laser diffraction method using a Beckman Coulter LS 13320 which measured fractions in 116 channels from $0.04 \mu \mathrm{m}$ up to $2000 \mu \mathrm{m}$. Bulk density was determined for the center of each of the four depth intervals using the gravimetric method, i.e. drying $100 \mathrm{~cm}^{3}$ samples at $60{ }^{\circ} \mathrm{C}$ until constant weight has been reached and weighing them on a precision balance.

For further analyses, we did not use the results of the separate depth intervals but used a weighted average: the separate results of the 4 sample depths were averaged to one measure by weighting the results of the different depths according to their volumetric share (e.g. depth $0-5 \mathrm{~cm}$ is $12.5 \%$ of the $0-40 \mathrm{~cm}$ soil).

The variability and correlation between soil characteristics was assessed with standardized principal component analysis for the plots used in the path analysis (Section 2.7.2). To improve interpretability, we used a Varimax rotation, retaining the first two axes, which explained $78 \%$ of the variation in the data (Fig. B.1). The first axis was positively associated with $\mathrm{N}$ and $\mathrm{C}$ content and negatively with bulk density, and is interpreted to represent a soil fertility gradient (Fig. B.1). It is therefore called soil fertility in the Results and Discussion sections. The second axis represents a gradient in soil texture: it is positively related with clay and negatively with sand (Fig. B.1).

\subsection{Estimation of aboveground biomass and biomass productivity}

We calculated biomass of woody species and palms. The aboveground biomass (AGB, in $\mathrm{Mg}$ ) of each tree was estimated using the best-fit pan tropical allometric model of Chave et al. (2015), requiring inputs on (i) wood density (WD), (ii) tree diameter at breast height (DBH) and (iii) tree height $(\mathrm{H})$.

$$
\mathrm{AGB}_{\mathrm{est}}=0.0673 *\left(\mathrm{WD} \mathrm{DBH}^{2} \mathrm{H}\right)^{0.976}
$$

Species-specific WD values were obtained from nearby sites if available (Verbeeck et al., 2014) and from the global wood density database (Chave et al., 2009; Zanne et al., 2009) for trees identified up to species or genus level (for which an average of the species of the same genus was used). For unidentified species and genera for which no WD data was found in literature, a plot level average was used. Heights were estimated from a locally developed $\mathrm{H}$ :DBH relationship based on the height of 1823 individual measured trees in this study (see Appendix $\mathrm{D}$ in SI). The AGB of oil palms (Elaeis guineensis) was calculated based on measured stem height after Hairiah et al., 2011:

$\mathrm{AGB}_{\text {est palm }}=0.0976 * \mathrm{H}+0.0706$

Biomass productivity, or mean annual biomass increment (ABI, $\mathrm{Mg} \mathrm{ha} \mathrm{h}^{-1} \mathrm{yr}^{-1}$ ) of each plot was calculated by dividing its AGB $\left(\mathrm{Mg} \mathrm{ha}^{-1}\right)$ by the age of its fallow (years). We refined this procedure by taking into account that at the onset of the fallow biomass could already be present in remnant trees. Therefore, we distinguished two types of biomass growth at plot level: (1) the biomass increment in non-remnant trees; and (2) the biomass increment in remnant trees at the time of measurement. Annual biomass increment in nonremnants (ABI_F) was calculated using the biomass in fallow trees (AGB_F) and the fallow age (yrs).

ABI_F $=$ AGB_F $* \mathrm{yrs}^{-1}\left(\mathrm{Mg} \mathrm{ha}^{-1} \mathrm{yr}^{-1}\right)$

Annual biomass increment in remnant trees (AGB_R) was calculated using an estimated biomass increment (AGB_inc) and the fallow age.

ABI_R $=$ AGB_inc $* \mathrm{yrs}^{-1}\left(\mathrm{Mg} \mathrm{ha}^{-1} \mathrm{yr}^{-1}\right)$

AGB_inc is the biomass increment in remnant trees since the start of the regeneration phase up to the time of measurement and was calculated as the difference between the biomass upon measurement minus the estimated biomass at the start of the fallow phase (AGBi). AGBi was estimated using Eq. (1), with the initial DBH $\left(D_{i}\right)$ calculated as the measured DBH minus the number of years under fallow multiplied by a yearly diameter increment (D_inc) (Eq. (5)); and with the initial height $(\mathrm{Hi})$ calculated from Di using the locally developed H:D relationship.

$\mathrm{D}_{\mathrm{i}}=\mathrm{D}-\mathrm{yrs} * \mathrm{D}$ _inc

There are no growth rates of remnant trees in the Congo basin available from the literature. For the D_inc we therefore used the average diameter increment for emergent and canopy trees from a natural forest stand in Cameroon (Worbes et al., 2003) $\left(0.47 \mathrm{~cm} \mathrm{yrs}^{-1}\right)$. In the remainder of the text, ABI refers to the sum of ABI_F and ABI_R.

Delcamp et al. (2008) found that growth of forest trees increases when the level of light increases due to logging. Here, we also expect the remnant trees to be stressed due to the burn and an abrupt change in the microclimate. We thus performed a sensitivity analysis on the ABI model and the outcomes of the piecewise structural equation model (Section 2.7.2) to the used diameter increment by increasing (representing more light availability and faster growth) and decreasing 
(representing stress from the burn and from disturbing the forest microclimate) D_inc with 50\% in the remnant biomass increment calculation. The ABI component models and the structural equation model results were found to be robust and were hardly affected by varying the used diameter increment rates in remnant trees (Table A.2). This is probably due to the rather limited presence and importance of remnants in many of the plots (present in 33\% of the plots, $12 \%$ of biomass on average across all plots, although in 8 out of 58 plots, remnants comprised $>50 \%$ of the biomass) and due to the comparably high diameter increment rates in the young pioneers vs. remnant trees (using the methods described above the share of total biomass growth having occurred in remnant trees was $2.7 \%$, with a max of $22 \%$ ).

\subsection{Statistical analyses}

\subsubsection{Variation in aboveground biomass in fallow fields}

The effects of fallow age, management history, soil and landscape and their interactions on aboveground biomass in fallow fields of differing age (3-27 years, $\mathrm{n}=96$ ) was assessed using an informationtheoretic approach (Burnham and Anderson, 2002). A limited set of regression models was constructed to test the major hypotheses of drivers of total aboveground biomass (Table A.3). The fallow age, the number of previous cycles, the share of biomass in remnant trees, soil sand fraction and surrounding forest cover were used as fixed factors in the AGB model. A similar approach was followed to build a model predicting biomass in remnant trees, using fallow age, the number of previous cycles, the number of spared trees and number of trees harvested for making charcoal as fixed factors. The models presented in the results were selected based on relative support for the potential models, which was expressed in AICcweights (Table A.4) (Burnham and Anderson, 2002). AICC adjusts AIC for small sample size. The models were linear mixed models, with villages (sites) as random effects. Models and model comparison were executed in $\mathrm{R}$ v.3.1.3 using packages nlme and AICcmodavg.

\subsubsection{Confirmatory path analysis of fallow biomass productivity}

We used confirmatory path analysis to examine how management history and landscape configuration could explain annual biomass productivity (both in remnant and non-remnant trees) through mediation of vegetation (weed invasion, functional diversity, functional identity and vegetation quantity) and soil characteristics.

To control for the effect of fallow age on biomass productivity and vegetation composition (through succession) we used a subset of 58 plots of more evenly-aged fallow fields with ages ranging from 5 to 10 years. This allowed us to attribute detected differences to management and plot properties.

Confirmatory path analysis is a form of structural equation modeling (SEM), which is an analysis to test support for an a priori defined network of causal relationships (Grace et al., 2010). The technique is based on piecewise fitting of component models (Lefcheck, 2015; Shipley, 2009). Piecewise SEM differs from traditional SEM as individual models (the different paths in the SEM or path model) can incorporate random structures and non-normal distributions by using mixed effects models. A subset of 58 plots aged 5 to 10 years was used to exclude as much as possible the effect of time on biomass regrowth rates and on vegetation succession.

Following the recommendations of Grace et al. (2012), we first conceived a meta-model of the system based upon knowledge of both system agro-ecology and biodiversity-ecosystem functioning (Fig. 1). This model represents how biomass productivity is linked to management history, landscape configuration and soil, either directly or indirectly through changes in weed invasion, vegetation properties and soil fertility. We expected that the vegetation properties were affected by management history and landscape configuration, and soil characteristics affected by management history. The changes in vegetation properties represent the mechanistic pathways that could explain differences in
$A B I$, which are based on the four previously introduced hypotheses (Fig. 1): (1) niche complementarity effect; (2) mass ratio effect; (3) vegetation quantity effect; and (4) weed invasion.

Next, we constructed a path model by choosing indicator variables for the theoretical model entities (Fig. 3A, full justification for the included paths given in Appendix C in SI). As multiple indicator variables were available for the vegetation properties, and to avoid multicollinearity (Fig. B.2), we selected one indicator for each of the four vegetation properties. Therefore, for each of the properties, we ran alternative mixed-effects models of $A B I$ (village as random effect), and retained the indicator that best predicted ABI (lowest AICC) (Table A.5, Fig. B.3). For the vegetation quantity effect, we compared stem density of woody stems $>5 \mathrm{~cm}$ diameter at breast height (DBH) and density of individuals (with at least one woody stem $>5 \mathrm{~cm}$ diameter at breast height (DBH)). As the two soil variables (PC-1 soil fertility and PC-2 soil texture) were not correlated, both were included in the path model. As we expected the management history variables to be correlated, we performed a multiple correspondence analysis (MCA) to visualize the main dimensions in management (Fig. B.4). We retained the number of previous cycles, the last fallow age and remnant tree biomass as predictors because we had clear hypotheses on their effect on the vegetation properties and were not strongly correlated. Harvesting intensity of construction and fuel wood were not retained because of correlations with the number of cycles. For landscape configuration, we used the area of old-growth forest cover in the surroundings as indicator. In the path model, the paths between the four vegetation properties and soil fertility were modeled as correlated errors, as we could not evaluate the causality of a relationship between these. We tested for multicollinearity in all of the regression models, and did not detect variance inflation factor (VIF) values higher than 2.5 , indicating that collinearity had a limited effect on the model results (Zuur et al., 2010). The goodness-of-fit of the path model was evaluated using Shipley's test of directed separation (Shipley, 2009), which gives a Fisher's C statistic that can be compared with a $\chi^{2}$-distribution, and AICc, which was calculated using Shipley's (Shipley, 2013) approach to computing AIC in path analyses. A significant $\chi^{2}$ statistic indicates that the path model does not fit the data well and that paths are missing. A first evaluation of the path model indicated that there was a missing path between soil texture and surrounding forest cover. As we lacked an explanation for this, we represented this path as a correlated error. Next, we calculated standardized effect sizes, and marginal and conditional $\mathrm{R}^{2}$ for each component model of the path model. Marginal and conditional $\mathrm{R}^{2}$ correspond to the variance explained by the fixed effect and the combined fixed and random effects, respectively (Nakagawa and Schielzeth, 2013). The goodness-of-fit tests, the AICc scores, and standardized effect sizes were calculated using the piecewiseSEM package (Lefcheck, 2015) in $\mathrm{R}$ version 3.1.3.

\section{Results}

\subsection{Drivers of fallow biomass}

Fallow fields had, on average, $58.4 \pm 46.2 \mathrm{Mg} \mathrm{ha}^{-1}$ aboveground biomass (AGB) (Table A.1). AGB generally increased with fallow age, but varied considerably between cycles (Fig. 2). The best AGB model included the number of previous cultivation cycles, age, share of remnant trees, sand, and an age: remnant share interaction as predictors (Table 2, Table A.3). Compared to first cycle fallow fields, AGB was significantly different in second cycle fallow fields (higher) and fallow fields having experienced four or more cycles (lower). Each additional year added $2.8 \mathrm{Mg}$ of biomass (on average over cycles, and assuming a zero share of remnants). We found a significant, positive interaction between age and remnant share, meaning that the effect of age on AGB increased in plots with higher remnant shares (crossover effect). We did not find a significant effect of sand content nor surrounding forest cover on AGB. 

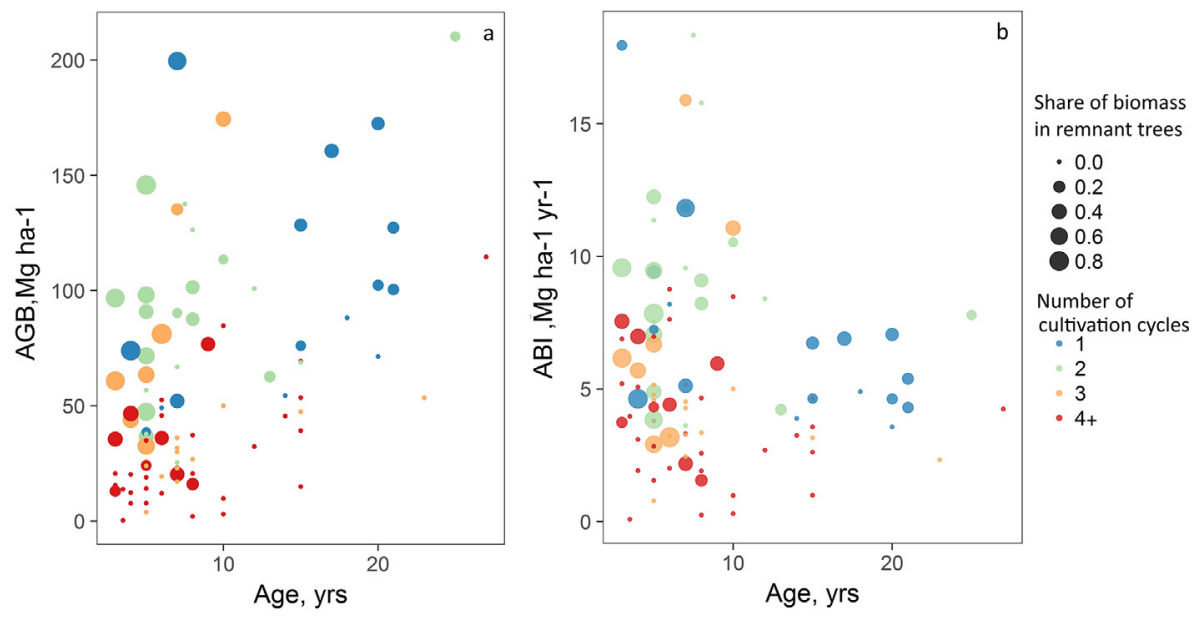

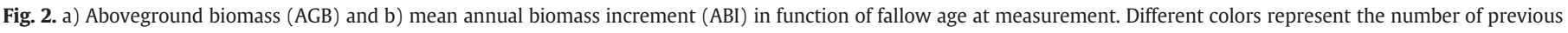

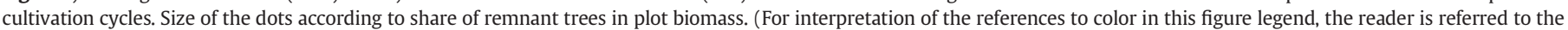
web version of this article.)

The biomass of remnant trees and its share in total plot biomass decreased with each cycle (Fig. B.5), and was determined by the number of trees the farmer decided not to cut down during field preparation (Table A.6). The share of biomass in remnant trees decreased with plot age, indicating that, in general, total biomass productivity in nonremnant trees was higher than in remnant trees (Table A.6).

\subsection{Drivers of biomass productivity}

Annual biomass increment ( $\mathrm{ABI}$ ) declined with plot age and varied substantially between cycles (Fig. 2).

We studied direct and indirect drivers of ABI using a subset of 58 plots aged 5 to 10 years (Table 3 ). The path model adequately reproduced the hypothesized causal network of effects of management history on $\mathrm{ABI}$ through changes in vegetation properties, weed invasion and soil (Fisher's C p-value $=0.35$, Table 4 ). The model explained $77 \%$ of the variation in ABI (Fig. 3, Table 4).

Management history strongly affected the functional identity and structure of the vegetation, either directly or indirectly through C. odorata invasion. Repeated slash and burn cycles led to a shift in species' relative dominance and growth share, with a notable decline in the dominance of Musanga cecropioides R. Br. (Moraceae) (umbrella tree or "parasolier") and Macaranga species from the third cycle onwards (Table A.8, Fig. B.6). In later cycles, the plant community had lower community weighted mean of max height growth rate (representation of trees able to gain height quickly, hereafter CWM max height growth), lower CWM mean DBH growth and lower max height, and higher CWM WD (Fig. 4c, Fig. B.7). The negative effect of the number of

Table 2

Final mixed linear regression model of aboveground biomass in fallows (age $<28$ yrs) in the three study sites.

\begin{tabular}{lccccc}
\hline \multicolumn{7}{l}{ Aboveground biomass } \\
\hline & Estimate & Std. error & $t$ & p value & Sign. level \\
\hline (Intercept) & 38.20 & 43.84 & 0.87 & 0.3861 & \\
CyclesC2 & 20.84 & 10.05 & 2.07 & 0.0412 & $*$ \\
CyclesC3 & -11.79 & 10.40 & -1.13 & 0.2601 & \\
CyclesC4 & -23.01 & 9.97 & -2.31 & 0.0235 & $*$ \\
Age & 2.83 & 0.69 & 4.09 & 0.0001 & $* * *$ \\
RemShare & -12.73 & 26.66 & -0.48 & 0.6341 & \\
Sand & -0.16 & 0.49 & -0.32 & 0.7522 & \multirow{2}{*}{ * } \\
Age:RemShare & 15.87 & 4.15 & 3.83 & 0.0002 & $*$ \\
\hline
\end{tabular}

Age: current age of fallow. Remshare: share of biomass in remnant trees. Cycle2-4: variable representing the number of previous slash and burn cycles. Sand: sand fraction. Significance levels: ${ }^{* * *} \mathrm{p}<0.001,{ }^{* *} \mathrm{p}<0.01,{ }^{*} \mathrm{p}<0.05$. previous cycles on CWM max height growth rate was both direct ( $\beta$ $=-0.47, \mathrm{p}<0.001)$ and indirectly through an increase in $C$. odorata cover $(\beta=-0.24, p=0.05$ ) (Figs. 3, 4c). CWM max height growth rate was also directly negatively affected by the biomass of remnant trees $(\beta=-0.38, p=0.002$ ) (Figs. 3, 4d). Stem density was negatively affected by the number of previous cycles, both directly $(\beta=-0.33, p$ $=0.017$, Fig. 3 ), and indirectly through an increase in $C$. odorata cover $(\beta=-0.38, p=0.001$, Fig. 3$)$. While stem density was similar in first and second cycle fallow fields, it decreased significantly in third and even more in four + cycle fallow fields (Fig. 4e). We observed significant differences in stem densities among villages which were not explained by the fixed effects (marginal $R^{2}$ of 0.26 versus conditional $R^{2}$ of 0.40 ): the random intercept of Bawi (-257) was significantly lower than those of Yambela (164) and Yaoseko (93). Diameter class distributions were similar between cycles, although decreases in stem density were most pronounced for smaller stems with $\mathrm{DBH}<15 \mathrm{~cm}$ (Fig. B.8). Soil fertility (soil PC-1) was negatively affected by the number of previous cycles $(\beta=-0.30, p=0.063)$. Models of the influence of management history variables on individual soil properties indicated that the $\mathrm{N}$ and C-contents significantly ( $\mathrm{p}<0.05$ ) declined with increasing numbers of previous cycles, and that sand and $\mathrm{N}$-content were lower in plots with longer previous fallow duration $(p<0.1)$ (Table A.10). Surrounding forest cover and the age at which the preceding fallow was cut did not affect vegetation properties. Functional richness was positively affected by the biomass of remnant trees $(\beta=0.24, \mathrm{p}=0.049)$. The previous number of slash and burn cycles itself was positively related to the intensity of fuel wood and construction wood harvesting, and negatively related to the number of large trees spared when slashing the preceding vegetation (Fig. B.4).

ABI was positively related to CWM max height growth rate (standardized $\beta=0.52, \mathrm{p}<0.001)$ and stem density $(\beta=0.28, \mathrm{p}=$ $0.014)$. Also the biomass of remnant trees $(0.23, \mathrm{p}=0.010)$ and soil fertility (PC-1) $(\beta=0.23, p=0.006)$ were significant predictors of $A B I$ (Fig. 3, Table A.7). ABI was not significantly related to either functional diversity or soil texture (PC-2) (Fig. 3, Table A.7).

The strongest pathway in the path model connecting management to productivity was a negative effect of the number of previous slash and burn cycles on ABI through a reduction in the CWM max height growth rate, while the second strongest pathway was through a reduction in stem density (Fig. 3).

There were significantly correlated error terms in the path model (Table A.7): between soil fertility and CWM max height growth rate ( $\beta$ $=0.26)$, soil fertility and $C$. odorata cover $(\beta=0.27)$; soil fertility and stem density $(\beta=0.33)$; stem density and CWM max height growth rate $(\beta=0.33)$, and stem density and functional richness $(\beta=0.24)$. 
Table 3

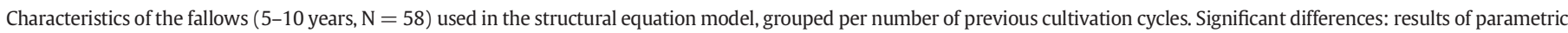
(Anova) and non-parametric (Kruskal-Wallis) tests.

\begin{tabular}{|c|c|c|c|c|c|c|c|c|c|c|}
\hline \multirow[t]{3}{*}{ \# cycles } & \multirow{2}{*}{\multicolumn{2}{|c|}{$\begin{array}{l}1 \text { cycle } \\
n=5\end{array}$}} & \multirow{2}{*}{\multicolumn{2}{|c|}{$\begin{array}{l}2 \text { cycles } \\
\mathrm{n}=16\end{array}$}} & \multirow{2}{*}{\multicolumn{2}{|c|}{$\frac{3 \text { cycles }}{n=17}$}} & \multirow{2}{*}{\multicolumn{2}{|c|}{$\begin{array}{l}4+\text { cycles } \\
n=20\end{array}$}} & \multirow{2}{*}{\multicolumn{2}{|c|}{ Sign. Diff }} \\
\hline & & & & & & & & & & \\
\hline & Mean & sd & Mean & sd & Mean & sd & Mean & sd & $F$ & $\mathrm{p}$ \\
\hline \multicolumn{11}{|l|}{ General } \\
\hline Age (years) & 6 & 1 & 6.4 & 1.6 & 6.6 & 1.6 & 7.1 & 1.8 & 0.89 & 0.451 \\
\hline $\mathrm{ABI}\left(\mathrm{Mg} \mathrm{ha}^{-1} \mathrm{yr}^{-1}\right)$ & $8.4^{\mathrm{a}, \mathrm{b}}$ & 2.5 & $9.5^{\mathrm{a}}$ & 4 & $5.1^{\mathrm{b}, \mathrm{c}}$ & 3.5 & $3.7^{c}$ & 2.6 & 10.19 & $<0.001$ \\
\hline \multicolumn{11}{|l|}{ Structure } \\
\hline $\mathrm{AGB}\left(\mathrm{Mg} \mathrm{ha}^{-1}\right)$ & $80.6^{\mathrm{a}, \mathrm{b}}$ & 67.1 & $83.4^{\mathrm{a}}$ & 36.8 & $46.9^{\mathrm{b}, \mathrm{c}}$ & 45 & $27.8^{\mathrm{c}}$ & 22.6 & 7.14 & $<0.001$ \\
\hline AGB Remnant ( $\left.\mathrm{Mg} \mathrm{ha}^{-1}\right)$ & $34.8^{\mathrm{a}}$ & 56.5 & $23.1^{\mathrm{a}, \mathrm{b}}$ & 30.5 & $13.1^{\mathrm{a}, \mathrm{b}}$ & 24.3 & $2.6^{\mathrm{b}}$ & 6.3 & 2.97 & 0.040 \\
\hline $\mathrm{BA}\left(\mathrm{m}^{2}\right)$ & $14.5^{\mathrm{a}, \mathrm{b}}$ & 7.5 & $16.7^{\mathrm{a}}$ & 6.7 & $9.5^{\mathrm{b}, \mathrm{c}}$ & 6.3 & $6.4^{\mathrm{c}}$ & 4.3 & 9.99 & $<0.001$ \\
\hline Stems $(>5 \mathrm{~cm})\left(\mathrm{ha}^{-1}\right)$ & $1106^{\mathrm{a}, \mathrm{b}}$ & 368 & $1031^{\mathrm{a}}$ & 288 & $770^{\mathrm{a}, \mathrm{b}, \mathrm{c}}$ & 283 & $519^{c}$ & 317 & 10.49 & $<0.001$ \\
\hline Individuals $(>5 \mathrm{~cm})\left(\mathrm{ha}^{-1}\right)$ & $957^{\mathrm{a}}$ & 419 & $763^{a, b}$ & 263 & $562^{\mathrm{b}}$ & 247 & $338^{c}$ & 196 & 12.77 & $<0.001$ \\
\hline Multist. ind. $(>5 \mathrm{~cm})\left(\mathrm{ha}^{-1}\right)$ & 92 & 48 & 160 & 82 & 110 & 72 & 91 & 85 & 2.52 & 0.067 \\
\hline Share multist. (\%) & 9 & & 21 & & 19 & & 27 & & & \\
\hline Tree height (m) & $13.2^{\mathrm{ab}}$ & 2.7 & $13.2^{\mathrm{a}}$ & 2.3 & $11^{\mathrm{ab}}$ & 3.6 & $10.4^{\mathrm{b}}$ & 2.9 & 3.31 & 0.027 \\
\hline WDw $\left(\mathrm{g} \mathrm{cm}^{-3}\right)$ & 0.52 & 0.04 & 0.53 & 0.04 & 0.55 & 0.04 & 0.55 & 0.05 & 1.20 & 0.306 \\
\hline $\mathrm{DBH}(\mathrm{cm})$ & 4.4 & 2.6 & 4.4 & 2.6 & 4.4 & 2.6 & 4.4 & 2.6 & 2.09 & 0.113 \\
\hline \multicolumn{11}{|l|}{ Diversity } \\
\hline Species richness & $15.2^{\mathrm{a}}$ & 4 & $14.5^{\mathrm{ab}}$ & 3.4 & $14.6^{\mathrm{ab}}$ & 4.3 & $11.3^{\mathrm{b}}$ & 4 & 3.23 & 0.029 \\
\hline Functional richness & 6.2 & 2.2 & 6.6 & 2.2 & 6.8 & 2.6 & 4.9 & 1.9 & 2.64 & 0.059 \\
\hline
\end{tabular}

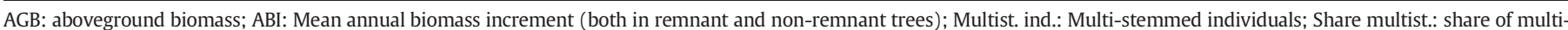

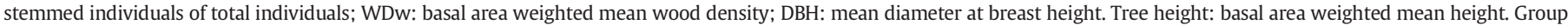
means not sharing a common letter differ significantly according to Tukey honestly significant difference tests.

\section{Discussion}

AGB in fallow fields and secondary forests in the Congo Basin increased with age of the fallow but varied considerably with management history, with significantly less biomass in fallow fields having undergone four or more cycles. Next, we found that the dominant way in which management history affects biomass productivity in young fallow fields is through the effect of the number of previous slash-and burn cycles on the functional identity and the quantity of the fallow vegetation.

\subsection{Effect of management history on functional identity in young fallows}

Management history strongly affected the functional identity of the fallow vegetation (Fig. 3). Our results demonstrate that repeated slash and burn cycles led to a more conservative plant community, with lower CWM max height growth rates, mean DBH growth and max height and higher CWM WD (Fig. 4, Fig. B.7). Here, we discuss a number of causal pathways through which the number of previous slash and burn cycles and remnant tree biomass could have caused the shift to a more conservative plant community. Previous management intensity has been observed to affect strongly the species composition and structure of secondary forests in slash and burn systems, by filtering out seed-dependent species and favoring strong sprouters and species that can cope with low nutrient availability (Jakovac et al., 2016, 2015), eventually leading to herbaceous fallows and eventually grassland if burning continues (Styger et al., 2007). In general, the abundance of certain species in young fallows is determined by their capacity to

Table 4

Model evaluation of path model and ABI component model.

\begin{tabular}{|c|c|c|c|c|c|c|c|}
\hline \multicolumn{4}{|c|}{ Path model evaluation } & \multicolumn{4}{|c|}{$\begin{array}{l}\text { ABI component model } \\
\text { evaluation }\end{array}$} \\
\hline Fisher C & Fisher $C \mathrm{p}$ value & K & $\mathrm{AICc}$ & K & $\mathrm{AICc}$ & $\mathrm{R} 2 \mathrm{~m}$ & $\mathrm{R} 2 \mathrm{c}$ \\
\hline 6.4 & 0.38 & 61 & -952.171 & 11 & 281.7 & 0.77 & 0.77 \\
\hline
\end{tabular}

Fisher $\mathrm{C}$ p-value is the null probability of comparing Fisher's $\mathrm{C}$ statistic used for the d-sep test to a $\chi^{2}$ distribution with $2 \mathrm{k}$ degrees of freedom, $\mathrm{K}$ is the number of parameters needed to fit the model, AICc is Akaike's information criterion for small sample sizes. $\mathrm{R}^{2} \mathrm{~m}$ : marginal $R^{2}$ (fixed effects only) and $R^{2} c$ : conditional $R^{2}$ (fixed + random effects). establish through seed and/or resprouting activity and their consequent growth, under the prevailing conditions of soil, water and microclimate and direct management interventions such as fire and weeding (Arroyo-Rodriguez et al., 2017; Jakovac et al., 2016). The number of previous cycles most strongly affected CWM max height growth rate (Fig. 3). This can be explained by a reduced presence of fast growing pioneers such as M. cecropioides and Macaranga sp., the former accounting for much of the biomass regrowth in the first two cycles (resp. 39 and $51 \%$, Fig. B.6). These species typically establish from seed (de Rouw, 1993), which is abundantly present in the soil seed bank of mature forests and old fallows (de Foresta and Schwartz, 1991; Douh et al., 2018). This suggests that their decline is due to a disappearance from the soil seed bank with repeated burning, cutting and weeding. Elsewhere in slash and burn systems species composition was affected by differences in tolerance to disturbance (Jakovac et al., 2016) and by the severity of the burn (temperature and duration) (de Foresta and Schwartz, 1991).

In our study, CWM max height growth rate was further negatively affected by the biomass of remnants and C. odorata cover (Fig. 3 ), indicating that shade conditions negatively affected seed germination and seedling establishment of pioneer species. In Cameroon, the early succession gap species $M$. cecropioides was more abundant away from remnant crowns, despite higher seed rain under remnant trees (Carrière et al., 2002a), suggesting that sufficient exposure to sunlight is needed for the germination of its seed. Alternatively, increased $C$. odorata cover may also result from a lesser presence of rapid growing pioneer species, as this herb degenerates in older fallows where trees provide shade (de Rouw, 1991a, 1991b).

Elsewhere, soil quality is another important determinant of species composition in fallows, favoring species that can cope with low nutrient availability (Jakovac et al., 2016). The significantly correlated error term between soil fertility and CWM max height growth rate (Table A.5) suggests that also in our study system reduced soil fertility could have been a cause of the observed change in functional identity. We could not determine causality, as changes in litter quality and quantity due to lower biomass growth of pioneers could also have affected soil fertility.

Surrounding forest cover did not affect the functional identity of the fallow fields (Fig. 3). Even in minimally disturbed landscapes with ample old growth forest, proximity to old growth forest has been observed to affect plant species richness and diversity (Jakovac et al., 2015; Klanderud et al., 2009; Norgrove and Beck, 2016; Robiglio and 


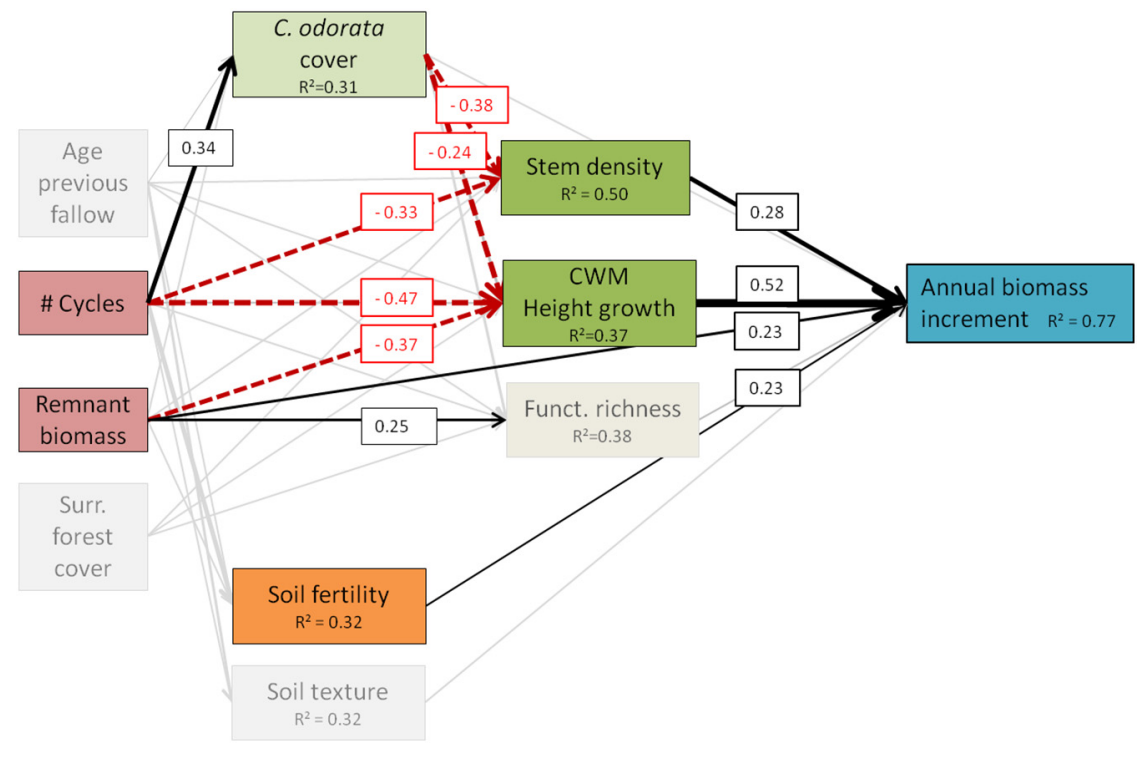

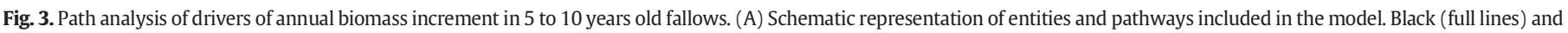

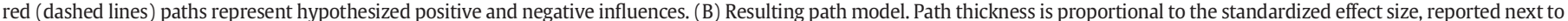

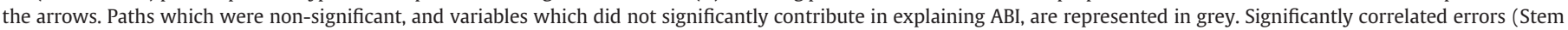

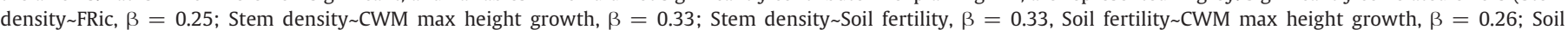

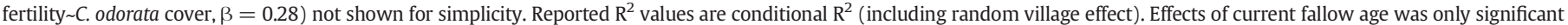
on $C$. odorata cover and are not shown for simplicity. (For interpretation of the references to color in this figure legend, the reader is referred to the web version of this article.)

Sinclair, 2011), although in other studies, the effect has not been significant (for example, Kupfer et al., 2004). Given that deforestation follows a radiating pattern from the village, surrounding forest cover was correlated to the number of slash-and-burn cycles (Spearman's $r=-0.54, \mathrm{p}$ $<0.001)$, which was a much better predictor of functional identity. However, we did not detect any effect as the role of landscape composition in overcoming seed-dispersal limitation is most obvious at later stages of succession.

\subsection{Effect of management history on stem density}

Management history also affected the fallow vegetation structure (Fig. 3). We observed important decreases in stem density after three and four slash and burn events (Fig. 4) and with increasing C. odorata cover (Fig. 3, Table A.7). Lower stem densities can result from (i) reduced regeneration chances from seed, (ii) reduced regeneration chances from resprouting, (iii) increased mortality of seedlings or shoots after establishment in the cropping phase or (iv) increasing intensity of harvesting of fuel and construction wood (Fig. B.4) as third and fourth cycle fallow fields are generally located closer to the village. Here, we observed both a reduction in seedlings and a reduction in resprouting ability (Fig. B.9), in line with observations in Ivory Coast (de Rouw, 1993). The main decline in stem density in the third and fourth cycle fallow fields was due to a decrease in individuals, but also the number of multi-stemmed individuals and shoots decreased from the second fallow onwards (Fig. B.9). As a result, in the fourth cycle almost half of the stems were resprouters, but in contrast to findings by Jakovac et al. (2015), total stem density declined with an increasing number of cycles. Although some of the individual stems might also be single-stemmed resprouts, the main trend is that repeated burning and weeding resulted in a strong decline in number of seedlings (see the decline in density of stems with $\mathrm{DBH}<10 \mathrm{~cm}$, Fig. B.8). The decline could be either due to lower germination, higher mortality or through harvesting (as the number of cycles and wood harvesting were correlated, Fig. B.4). This supports observations in the Amazon of an increased proportion of sprout-dependent regeneration and a decreased seed-dependent regeneration due to (i) repeated burning and weeding (Jakovac et al., 2015), leading to depletion of the soil seed bank (de Rouw, 1993; Lawrence et al., 2005; J.M. Tucker et al., 1998) and (ii) weeding of weak-rooted seedlings (as opposed to better established sprout roots). Additionally, the strong effect of $C$. odorata cover on stem density suggests that germination and/or survival of pioneer species were severely compromised. Establishment of pioneers has been found to suffer from the invasion of fast-spreading weeds such as C. odorata in other shifting cultivation systems (de Foresta and Schwartz, 1991; Ngobo et al., 2004; Styger et al., 2007), either through their out-shading capacity (te Beest et al., 2014) or allelopathic effects. The lower stem density in Bawi was partially explained by higher C. odorata cover, and could further be explained by more intense fuel and construction wood harvesting in the fallows, shorter (historic) average fallow durations, or less seed dispersion by animals because of higher hunting and trapping pressure. Remnant biomass did not affect stem density (Fig. 3), potentially because we did not distinguish between the effect of remnants on late-successional species and pioneer species, whose establishment is expected to be affected differently (Carrière et al., 2002b). Further unexplained variation in stem density might be due to the severity of the burn (de Rouw, 1993; Norgrove and Hauser, 2015).

\subsection{Effects of vegetation properties on biomass productivity}

Our results indicate that in early successional stages, the abundant presence of individuals that can capture the abundantly available resources (e.g. light) and use them for rapid growth is the main driver of biomass productivity. The six tested CWM trait values were all significant predictors of $\mathrm{ABI}$ in bivariate analyses, but only CWM max height growth and CWM mean DBH growth explained more than a third of the variance and were found plausible based on $\triangle$ AICc (Table A.5). Community-weighted mean of specific leaf area has been found to positively affect biomass productivity in fallows (Ali et al., 2017; Lohbeck et al., 2015) and forests (Finegan et al., 2015) in the humid tropics, suggesting a positive effect of domination of species that effectively capture light and resources. While we find a positive relation between $\mathrm{ABI}$ and the CWM of leaf traits associated with acquisitive strategies (leaf $\mathrm{N}$ and SLA) (Table 4), only SLA was a significant predictor of ABI when accounting for stem density (results not shown). Economic traits that lead to greater light harvesting (SLA) and great photosynthetic potential (N) generally lead to greater C uptake (Reich, 2014), but given that 

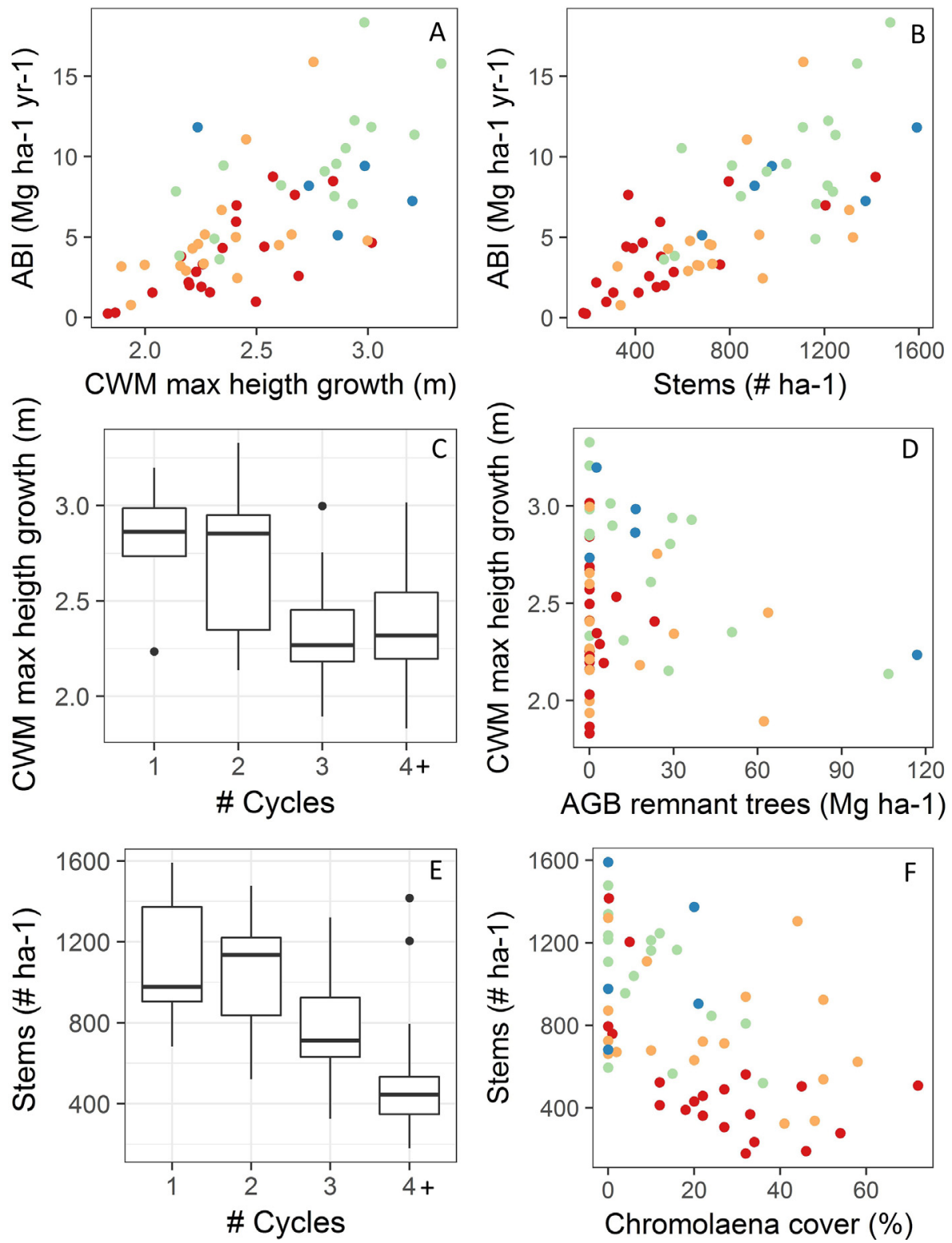

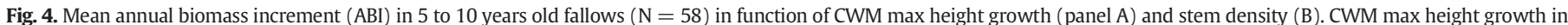

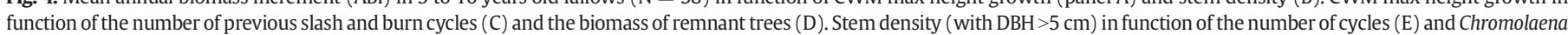

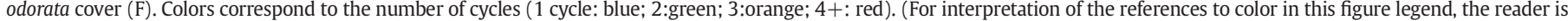
referred to the web version of this article.)

they are often correlated with lower WD relations with biomass are not consistently found. However, the significant effects of the CWM of DBH growth and height growth rates (and negative relation with wood density) clearly suggests that the dominance of rapid growth species is an important driver of $\mathrm{ABI}$ in these fallow fields, thus giving support to the mass ratio hypothesis.

The second strongest effect of the vegetation properties on $A B I$ was the stem density of stems with $\mathrm{DBH}>5 \mathrm{~cm}$ (Fig. 3), meaning that ABI also varied with the number of seedlings and resprouts. Density of trees with $\mathrm{DBH}>10 \mathrm{~cm}$ was also found to be an important driver of $\mathrm{ABI}$ in fallows following different numbers of prior cultivation cycles (Lawrence, 2005). Other studies found lower ABI or basal area associated with higher stem densities (Jakovac et al., 2015; Williamson et al., 2014) due to a shift to sprout-dependent regeneration mechanisms resulting in many small stems, but these studies included stems up to or below $1 \mathrm{~cm}$ in diameter. As the resultant rather than the initial stem density was used in our models, the causality of the relation between stem density and biomass productivity could be questioned.
Both the recruitment of new stems and stem mortality during the succession from field abandonment to the moment of field measurement could have altered the stem density with time. However, in line with a chronosequence study in secondary forests in the Amazon (Williamson et al., 2014), no clear evolution in stem density was observed (Fig. B.10), indicating that for the given age class (5-10 years) the measured stem density is a good indication of initial stem density. We did not find support for an effect of functional diversity, as the effect of functional richness on ABI was small and non-significant (Table A.7, Fig. 3). This is probably because stands dominated by a fast-growing species are more productive than more diverse communities comprised of both fast growing pioneers and other, less productive species. In contrast, positive diversity- $\Delta$ biomass correlations were found in early successional forests (Lasky et al., 2014), but these stands were $>10$ years old.

Although in our study functional identity was most important, the dominant effects of functional identity and of vegetation quantity on biomass productivity and the lesser effect of functional diversity are in 
line with findings of a study in tropical wet forest in Mexico (Lohbeck et al., 2015). However, as the time-scale of our study and the definition of vegetation quantity differed from Lohbeck, more studies are needed to compare the relative importance of vegetation properties on biomass growth in fallows.

\subsection{Main pathways linking management history to biomass productivity}

Biomass productivity in fallows has been found to be driven by management history, by changes in soil (Delang and Li, 2013) and vegetation properties (Ali et al., 2017; Finegan et al., 2015; Lohbeck et al., 2015), and by landscape configuration. Here, we compared the relative importance of these drivers. We found that management history mainly affected biomass productivity through a change in functional identity and structure of the vegetation. In line with our hypothesis, the strongest pathway in the path model was a negative effect of the number of previous slash and burn cycles on ABI through a reduction in the CWM max height growth rate (Fig. 3). The second strongest effect of management on $\mathrm{ABI}$ was through a reduction in stem density of stems with $\mathrm{DBH}>5 \mathrm{~cm}$ (Fig. 3). We thus demonstrate, for the first time, that fallow biomass decline in successive slash and burn cycles is due to changes in fallow functional identity. This can explain unexplained variance in similar studies (Lawrence et al., 2010; Wood et al., 2017).

The effect of remnant biomass on $\mathrm{ABI}$ was balanced out: while we found a directly positive effect, we found an indirect negative effect through a reduction in the CWM max height growth rate (Fig. 3). Surrounding forest cover did not significantly affect biomass productivity, as it did not affect any of its direct predictors (Fig. 3, Sections 4.2 and 4.3). This is in line with recent observations in secondary forests in the neo-tropics (Poorter et al., 2016) and findings that management was more important than landscape configuration to explain biomass growth in young fallows (Jakovac et al., 2016).

Biomass regeneration was positively correlated to soil fertility, but the mediating effect of soil fertility on $A B I$ was smaller than that of stem density and functional identity (Fig. 3). The number of cycles was the most important predictor of soil fertility, related to decline in soil N- and C-contents (Table A.10), but the effect was only marginally significant (Table A.7). Soil fertility declines are linked to nutrient losses from the system due to volatilization and leaching during and after burning (Hughes et al., 2000; Palm et al., 1996; Ribeiro Filho et al., 2015; Wood et al., 2017). The mediating effect of a decline in soil fertility in linking repeated slash and burn cycles with reductions in biomass recovery is often reported (Lawrence et al., 2007; Moran et al., 2000). However, neither the effect of management history on declining soil fertility, nor the effect of soil fertility on declining biomass recovery are consistently found (Delang and Li, 2013; Jakovac et al., 2015).

While we did find evidence for a pathway from repeated cultivation to decreased soil fertility to decreased ABI, more data on soil fertility at the start of the fallow would be needed to assess the causal importance of this pathway. Indeed, the observed soil nutrients could also have been affected by variation in litter fall due to differences in ABI and changes in the functional composition of the vegetation (Bauters et al., 2017). Sufficiently long fallow periods are thought to compensate for soil nutrient losses through aboveground (litter fall) and belowground (biomass decomposition) inputs (Palm et al., 1996). Therefore, and because of its effect on potential yield-limiting factors such as weeds and pests, fallow age is an important indicator for plot selection in West and Central Africa (Norgrove and Hauser, 2016). Here, the relation between fallow duration in the previous cycle and soil fertility was negative but not significant. Our findings need not contradict the concept that soil improves with fallow duration. However, our age range was limited, and we did not do repeated sampling. As farmers may choose to increase fallow duration on poorer soils (Junqueira et al., 2016), longer previous fallow ages in this case could be correlated to less favorable soil conditions and plant growth. In general, the ratio of total cropping duration over total fallow duration is probably a better indicator which could further help explain residual variance in the path model.

\subsection{Implications for ecosystem services in shifting cultivation landscapes}

The value of secondary forests for climate change mitigation has recently been highlighted (Houghton et al., 2015; Poorter et al., 2016). However, some studies assessing carbon emissions from tropical deforestation (e.g. Zarin et al., 2016) incorrectly assume a stable shifting cultivation system with full biomass recovery up to the level of the previous cycle. While the carbon sequestration rates in fallow fields in our study area are similar to averages reported from the Neotropics and thus corroborate their (limited) potential for climate change mitigation, our results are also in line with observations of Akkermans et al. (2013) noting that the carbon reservoir within the shifting cultivation system in our study region is decreasing in size. While long-term negative carbon outcome of swiddens have been reported frequently (review by Lawrence et al., 2010, but exceptions exist, see Wood et al., 2017), declines observed in this study were at the higher end of the reported spectrum. Recovery rates were low from the third cycle onwards (Table 3, Fig. 4), with ABI in the four + cycle fallow fields being on average only $42 \%$ of $\mathrm{ABI}$ of the first and second cycle. For a given age (between 5 and 10 years), four + cycle fallow fields store only about onethird of the carbon of first cycle fallow fields. This means that, given current fallow lengths, carbon stocks within the shifting cultivation landscape will continue to decline, unless measures are taken to increase biomass regeneration. These values can also inform us on the carbon outcomes of intended agricultural sedentarization and intensification in the DRC (RD Congo, 2015) and of shifts to perennial crops. We found that the share of biomass in remnant trees also has a significant effect on biomass stocks in fallows, especially in first and second cycles. Preserving certain trees in fields is an ancient and common practice in Central and West Africa, which is done for deliberate purposes, is culturally determined, and is subject to change depending on factors such as market forces, population growth and social change (see Carrière, 2002 for an overview). In our study area, some trees are deliberately spared to perform different functions during the cropping phase, the provision of non-timber-forest products being the most important (Okangola Ekeli, 2007). Time-averaged carbon stocks (averaged over the growing period, e.g. Palm et al., 1999) in first and second cycle fallow fields ( $50 \mathrm{Mg} \mathrm{ha}^{-1}$ obtained by a calculation assuming a linear biomass growth) are slightly higher than time-averaged stocks in oil palm plantations (around $40 \mathrm{Mg} \mathrm{ha}^{-1}$ after 25 years (Khasanah et al., 2015)), lower than cacao agroforests (100 $\mathrm{Mg} \mathrm{ha}^{-1}$, (Kotto-same et al., 1997)) and higher than in permanent cropping systems (Kotto-same et al., 1997). From the third and fourth generation onwards carbon benefits of a shift to more permanent cropping systems become more frequent. The increased abundance of oil palms in the four + cycle fallow fields already partially makes up for the loss of regeneration in other species but could be further stimulated. In addition, given that changes in stem density and in the functional identity of the vegetation were found to explain reduced biomass regeneration, it is worthwhile to further investigate how stem density, especially of fast growing species, can be maintained or improved to maintain ecosystem functioning and associated ecosystem services.

While carbon sequestration is linearly related to biomass recovery, soil fertility restoration is more complex as it depends on the functional identity of the vegetation community (Bauters et al., 2017), varies with fallow age (Bartholomew et al., 1953) and is nutrient specific. In any case, the very low soil $\mathrm{C}$ and $\mathrm{N}$ contents we find, suggest that most of the nutrients for crop growth must come from the biomass, whose regeneration is slowing down from the third cycle onwards. For short fallows, grass fallows were observed to have faster nutrient uptake rates than forest fallows (Bartholomew et al., 1953). A similar process is likely playing a role with $C$. odorata, which is known by farmers in the study area (personal communication) and elsewhere in West and Central 
Africa as an indicator of soil fertility (Norgrove and Hauser, 2016). Thus, while $C$. odorata hampers forest succession, in situations with short fallow cycles its overall role might be beneficial in terms of nutrient restoration (Koné et al., 2012), prevention of leaching and soil compaction and in terms of labor efficiency (de Rouw, 1991a, 1991b; Hauser and Mekoa, 2009; Norgrove et al., 2000).

Farmers deliberately manage fields to allow biomass regeneration to suppress understory weeds and restore soil fertility by limiting the cultivating period and not removing all root stumps. Given the increasing scarcity of land, fallow duration is now shorter than the traditionally preferred duration. However, rapid regeneration of fallow biomass is only one of the farmers' management objectives, and these objectives differ depending on plot history. In each of the communities, a fallow typology exists which is predominantly determined by the number of previous cultivation cycles. These types differ in labor investment (for slashing undergrowth, clearing trees and weeding), environmental conditions (soil fertility, light, humidity) and thus crop choice and yields. Thus, rather than aiming to maintain high biomass recovery, interventions (e.g. introduction of trees or herbaceous legumes) could be chosen in line with the functions that the different fallow types serve in farmers' food and revenue generation (Hauser et al., 2006).

\section{Conclusions}

This study demonstrated how management legacies affect biomass accumulation in fallows through changes in vegetation properties, including composition and structure, and soil. While aboveground biomass generally increased with fallow age, considerable variation was found in succession dynamics. Biomass accumulation rates in fallow fields aged 5-10 years varied with the number of previous slash-andburn cycles, with notable declines in the fourth cycle. Both the dominance of species with rapid growth strategies and the density of regenerating individuals exerted most control on aboveground biomass increment (ABI). The functional identity itself was determined by both the number of cultivation cycles and biomass of remnant trees, while stem density was determined by the number of cultivation cycles. The effect of the number of cultivation cycles was partly through an increase in $C$. odorata cover. We recommend that assessments of carbon stocks at landscape scale in shifting cultivation systems in the humid forest zone of Central Africa should take heterogeneity in biomass stocks and decrease of biomass recovery with increasing slash-and-burn cycles into account. Our findings suggest that under current management intensity the capacity of the shifting cultivation system in providing important ecosystem functions such as carbon sequestration and soil fertility restoration is declining.

\section{Acknowledgments}

This research was funded by the Flemish Interuniversity Council University Development Cooperation (VLIR-UOS) through the DEFIproject and a VLADOC grant for P.M. B.V. is funded by KLIMOS, the ACROPOLIS platform on generating capacity for sustainability transition, for which funding is provided by DGD (the Belgian Directorate General for Development Cooperation) through VLIR-UOS and ARES. Trait data collection by E.K. was done in the framework of the COBIMFO project (Congo Basin integrated monitoring for forest carbon mitigation and biodiversity; contract no. SD/AR/01A) and was funded by the Belgian Science Policy Office (BELSPO). The authors wish to thank the University of Kisangani and collaborators, in particular Anaclet Lisiko Boyemba, for their help and support with data collection. We thank Lore Fondu and Remi Chevalier for considerable help with soil analyses. The local communities are gratefully acknowledged for granting access to their forest and for contributing to the study by sharing their knowledge and helping with data collection. The study has been supported by the TRY initiative on plant traits (http://www.try-db.org). The TRY initiative and database is hosted, developed and maintained by J. Kattge and G.
Bönisch (Max Planck Institute for Biogeochemistry, Jena, Germany). TRY is currently supported by DIVERSITAS/Future Earth and the German Centre for Integrative Biodiversity Research (iDiv) Halle-Jena-Leipzig. We thank four anonymous reviewers for their constructive comments on an earlier version of the manuscript.

\section{Appendix. Supplementary information}

Supplementary information to this article can be found online at https://doi.org/10.1016/j.scitotenv.2018.12.138.

\section{References}

Akkermans, T., Van Rompaey, A., Van Lipzig, N., Moonen, P., Verbist, B., 2013. Quantifying successional land cover after clearing of tropical rainforest along forest frontiers in the Congo Basin. Phys. Geogr. 34, 417-440. https://doi.org/10.1080/ 02723646.2013.855698.

Ali, A., Yan, E.R., Chang, S.X., Cheng, J.Y., Liu, X.Y., 2017. Community-weighted mean of leaf traits and divergence of wood traits predict aboveground biomass in secondary subtropical forests. Sci. Total Environ. 574, 654-662. https://doi.org/10.1016/j scitotenv.2016.09.022.

Arroyo-Rodriguez, V., Melo, F.P.L., Martinez-Ramos, M., Bongers, F., Chazdon, R.L., Meave, J.A., Norden, N., Santos, B.A., Leal, I.R., Tabarelli, M., 2017. Multiple successional pathways in human-modified tropical landscapes: new insights from forest succession, forest fragmentation and landscape ecology research. Biol. Rev. 92, 326-340. https://doi.org/10.1111/brv.12231.

Aweto, A.O., 1981. Secondary succession and soil fertility restoration in south-western Nigeria. II. Soil fertility restoration. J. Ecol. 69, 609-614.

Aweto, A.O., 2012. Shifting Cultivation and Secondary Succession in the Tropics. CABI Publishing, University of Ibadan, Nigeria.

Bartholomew, W.V., Meyer, J., Laudelout, H., 1953. Mineral Nutrient Immobilization Under Forest and Grass Fallow in the Yangambi (Belgian Congo) Region. INEAC

Bastin, J.-F., Barbier, N., Réjou-Méchain, M., Fayolle, A., Gourlet-Fleury, S., Maniatis, D., de Haulleville, T., Baya, F., Beeckman, H., Beina, D., Couteron, P., Chuyong, G., Dauby, G., Doucet, J.-L., Droissart, V., Dufrêne, M., Ewango, C., Gillet, J.F., Gonmadje, C.H., Hart, T., Kavali, T., Kenfack, D., Libalah, M., Malhi, Y., Makana, J.-R., Pélissier, R., Ploton, P., Serckx, A., Sonké, B., Stevart, T., Thomas, D.W., De Cannière, C., Bogaert, J., 2015. Seeing Central African forests through their largest trees. Sci. Rep. 5, 13156. https://doi. org/10.1038/srep13156.

Bauters, M., Verbeeck, H., Doetterl, S., Ampoorter, E., Baert, G., Vermeir, P., Verheyen, K., Boeckx, P., 2017. Functional composition of tree communities changed topsoil properties in an old experimental tropical plantation. Ecosystems 20,861-871. https:// doi.org/10.1007/s10021-016-0081-0.

Becknell, J.M., Powers, J.S., 2014. Stand age and soils as drivers of plant functional traits and aboveground biomass in secondary tropical dry forest. Can. J. For. Res. 44 604-613. https://doi.org/10.1139/cjfr-2013-0331.

Bongers, F., Chazdon, R., Poorter, L., Peña-Claros, M., 2015. The potential of secondary forests. Science 348, 642-643. https://doi.org/10.1126/science.348.6235.642-c.

Bu, W., Zang, R., Ding, Y., 2014. Field observed relationships between biodiversity and ecosystem functioning during secondary succession in a tropical lowland rainforest. Acta Oecol. 55, 1-7. https://doi.org/10.1016/j.actao.2013.10.002.

Burnham, K.P., Anderson, D.R., 2002. Model selection and multimodel inference: a practical information-theoretic approach. Ecological Modelling, 2nd ed. Springer-Verlag, New York, New York https://doi.org/10.1016/j.ecolmodel.2003.11.004.

Cardinale, B.J., Duffy, J.E., Gonzalez, A., Hooper, D.U., Perrings, C., Venail, P., Narwani, A., Mace, G.M., Tilman, D., Wardle, D.A., Kinzig, A.P., Daily, G.C., Loreau, M., Grace, J.B. Larigauderie, A., Srivastava, D.S., Naeem, S., 2012. Biodiversity loss and its impact on humanity. Nature 489, 59-69. https://doi.org/10.1038/nature11373.

Carrière, S., 2002. "Orphan trees of the forest": why do Ntumo farmers of southern Cameroon protect trees in their swidden fields? J. Ethnobiol. 22, 133-162.

Carrière, S., Andre, M., Letourmy, P., Olivier, I., McKey, D.B., 2002a. Seed rain beneath remnant trees in a slash-and-burn agricultural system in southern Cameroon. J. Trop. Ecol. 18, 353-374. https://doi.org/10.1017/s0266467402002250.

Carrière, S., Letourmy, P., McKey, D.B., 2002b. Effects of remnant trees in fallows on diversity and structure of forest regrowth in a slash-and-burn agricultural system in southern Cameroon. J. Trop. Ecol. 18, 375-396. https://doi.org/10.1017/ S0266467402002262.

Chave, J., Coomes, D., Jansen, S., Lewis, S.L., Swenson, N.G., Zanne, A.E., 2009. Towards a worldwide wood economics spectrum. Ecol. Lett. 12, 351-366. https://doi.org/ 10.1111/j.1461-0248.2009.01285.x.

Chave, J., Réjou-Méchain, M., Búrquez, A., Chidumayo, E., Colgan, M.S., Delitti, W.B.C. Duque, A., Eid, T., Fearnside, P.M., Goodman, R.C., Henry, M., Martínez-Yrízar, A., Mugasha, W.A., Muller-Landau, H.C., Mencuccini, M., Nelson, B.W., Ngomanda, A. Nogueira, E.M., Ortiz-Malavassi, E., Pélissier, R., Ploton, P., Ryan, C.M., Saldarriaga, J.G., Vieilledent, G., 2015. Improved allometric models to estimate the aboveground biomass of tropical trees. Glob. Chang. Biol. 20, 3177-3190. https://doi.org/10.1111/ gcb.12629.

de Foresta, H., Schwartz, D., 1991. Chromolaena odorata and disturbance of natural succession after shifting cultivation: an example from Mayombe, Congo, Central Africa. Proceedings of the Second International Workshop on Biological Control of Chromolaena odorata. Orstom, Bogor, Indonesia, p. 21 
de Rouw, A., 1991a. The invasion of Chromolaena odorata (L.) King \& Robinson (ex Eupatorium odoratum), and com petition with the native flora, in a rain forest zone, south-west Côte d'Ivoire. J. Biogeogr. 18, 13-23.

de Rouw, A., 1991b. Rice, Weeds and Shifting Cultivation in a Tropical Rain Forest. A Study of Vegetation Dynamics. Wageningen University, Wageningen, The Netherlands.

de Rouw, A., 1993. Regeneration by sprouting in slash and burn rice cultivation, tai rain forest, Cote d'Ivoire. J. Trop. Ecol. 9, 387-408.

Delang, C.O., Li, W.M., 2013. Ecological Succession on Fallowed Shifting Cultivation Fields. A Review of the Literature. Springer.

Delcamp, M., Gourlet-Fleury, S., Flores, O., Garnier, E., 2008. Can functional classification of tropical trees predict population dynamics after disturbance? J. Veg. Sci. 19, 209-220. https://doi.org/10.3170/2008-8-18360.

Díaz, S., Lavorel, S., de Bello, F., Quétier, F., Grigulis, K., Robson, T.M., 2007. Incorporating plant functional diversity effects in ecosystem service assessments. Proc. Natl. Acad. Sci. U. S. A. 104, 20684-20689. https://doi.org/10.1073/pnas.0704716104.

Douh, C., Daïnou, K., Joël, J., Moutsambote, J., 2018. Soil seed bank characteristics in two central African forest types and implications for forest restoration. For. Ecol. Manag. 409, 766-776. https://doi.org/10.1016/j.foreco.2017.12.012.

Dowiya, N.B., Rweyemamu, C.L., Maerere, A.P., 2009. Banana (Musa spp. Colla) cropping systems, production constraints and cultivar preferences in eastern Democratic Republic of Congo. J. Anim. Plant Sci. 4, 341-356.

Eaton, J.M., Lawrence, D., 2009. Loss of carbon sequestration potential after several decades of shifting cultivation in the Southern Yucatán. For. Ecol. Manag. 258, 949-958. https://doi.org/10.1016/j.foreco.2008.10.019.

FAO, 2015. Global Forest Resources Assessment 2015.

Finegan, B., Peña-Claros, M., Oliveira, A., Alarcón, A., Ascarrunz, N., Bret-Harte, M., Carreño-Rocabado, G., Casanoves, F., Díaz, S., Eguiguren, P., Fernandez, F., Lorenzo, L., Salgado, B., Lourens Poorter, M., 2015. Does functional trait diversity predict aboveground biomass and productivity of tropical forests? Testing the biomass ratio-, niche complementarity, and green soup hypotheses. J. Ecol. 191-201. https://doi.org/ 10.1111/1365-2745.12346.

Garnier, E., Cortez, J., Billes, G., Navas, M.-L., Roumet, C., Debussche, M., Laurent, G., Blanchard, A., Aubry, D., Bellmann, A., Neill, C., Toussaint, J.-P., 2004. Plant functional markers capture ecosystem properties during secondary succession. Ecology 85, 2630-2637.

Gilson, P., Van Wambeke, A., Gutzweiler, R., 1956. Notice explicative de la carte des sols et de la végétation, No. 6: Yangambi, planchette 2: Yangambi. INEAC, Bruxelles.

Gourlet-fleury, S., Rossi, V., Rejou-mechain, M., Freycon, V., Cornu, G., Ge, J., Fayolle, A. Saint-andre, L., Billand, A., Fauvet, N., Sarrailh, J., Flores, O., Gally, M., Henry, M., Hubert, D., Pasquier, A., 2011. Environmental filtering of dense-wooded species controls above-ground biomass stored in African moist forests. J. Ecol. 99, 981-990. https://doi.org/10.1111/j.1365-2745.2011.01829.x.

Grace, J.B., Anderson, T.M., Olff, H., Scheiner, S.M., 2010. On the specification of structural equation models for ecological systems. Ecol. Monogr. 80, 67-87. https://doi.org/ 10.1890/09-0464.1.

Grace, J.B., Schoolmaster, D.R., Guntenspergen, G.R., Little, A.M., Mitchell, B.R., Miller, K.M. Schweiger, E.W., 2012. Guidelines for a graph-theoretic implementation of structural equation modeling. Ecosphere 3. https://doi.org/10.1890/ES12-00048.1 art73.

Grime, J.P., 1998. Benefits of plant diversity to ecosystems: immediate, filter and founder effects. J. Ecol. 86, 902-910.

Hairiah, K., Dewi, S., Agus, F., Velarde, S., Ekadinata, A., Rahayu, S., van Noordwijk, M. 2011. Measuring Carbon Stocks Across Land Use Systems. World Agroforestry Centre (ICRAF), SEA Regional Office, Bogor, Indonesia.

Hauser, S., Mekoa, C., 2009. Biomass production and nutrient uptake of Chromolaen odorata as compared with other weeds in a burned and a mulched secondary forest clearing planted to plantain (Musa spp.). Weed Res. 49, 193-200. https://doi.org/ 10.1111/j.1365-3180.2008.00685.x.

Hauser, S., Nolte, C., Carsky, R.J., 2006. What role can planted fallows play in the humid and sub-humid zone of West and Central Africa? Nutr. Cycl. Agroecosyst. 76, 297-318. https://doi.org/10.1007/s10705-005-5630-4.

Heinimann, A., Mertz, O., Frolking, S., Christensen, A.E., Hurni, K., Sedano, F., Chini, L.P., Sahajpal, R., Hansen, M., Hurtt, G., 2017. A global view of shifting cultivation: recent, current, and future extent. PLoS One 12,1-21. https://doi.org/10.1371/journal. pone. 0184479 .

Houghton, R.A., Byers, B., Nassikas, A.A., 2015. A role for tropical forests in stabilizing atmospheric $\mathrm{CO}_{2}$. Nat. Clim. Chang. 5, 1022-1023. https://doi.org/10.1038/ nclimate2869.

Hughes, R.F., Kauffman, J., Cummings, D.L., 2000. Fire in the Brazilian Amazon. Oecologia 124, 574-588. https://doi.org/10.1007/s004420000416.

Ickowitz, A., Slayback, D., Asanzi, P., Nasi, R., 2015. Agriculture and Deforestation in the Democratic Republic of the Congo (No. 119), Occasional Paper. Indonesia, Bogor.

Jakovac, C.C., Peña-Claros, M., Kuyper, T.W., Bongers, F., 2015. Loss of secondary-forest resilience by land-use intensification in the Amazon. J. Ecol. 103, 67-77. https://doi.org/ 10.1111/1365-2745.12298.

Jakovac, C.C., Bongers, F., Kuyper, T.W., Mesquita, R.C.G., Peña-Claros, M., 2016. Land use as a filter for species composition in Amazonian secondary forests. J. Veg. Sci. https://doi.org/10.1111/jvs.12457.

Jalloh, A., Roy-Macauley, H., Sereme, P., 2012. Major agro-ecosystems of West and Central Africa: brief description, species richness, management, environmental limitations and concerns. Agric. Ecosyst. Environ. 157, 5-16. https://doi.org/10.1016/j. agee.2011.11.019.

Junqueira, A.B., Stomph, T.J., Clement, C.R., Struik, P.C., 2016. Variation in soil fertility influences cycle dynamics and crop diversity in shifting cultivation systems. Agric. Ecosyst. Environ. 215, 122-132. https://doi.org/10.1016/j.agee.2015.09.015.

Kattge, J., Díaz, S., Lavorel, S., Prentice, I.C., Leadley, P., Bönisch, G., Garnier, E., Westoby, M. Reich, P.B., Wright, I.J., Cornelissen, J.H.C., Violle, C., Harrison, S.P., Van Bodegom, P.M.,
Reichstein, M., Enquist, B.J., Soudzilovskaia, N.A., Ackerly, D.D., Anand, M., Atkin, O., Bahn, M., Baker, T.R., Baldocchi, D., Bekker, R., Blanco, C.C., Blonder, B., Bond, W.J., Bradstock, R., Bunker, D.E., Casanoves, F., Cavender-Bares, J., Chambers, J.Q., Chapin, F.S., Chave, J., Coomes, D., Cornwell, W.K., Craine, J.M., Dobrin, B.H., Duarte, L., Durka, W., Elser, J., Esser, G., Estiarte, M., Fagan, W.F., Fang, J., Fernández-Méndez, F., Fidelis, A., Finegan, B., Flores, O., Ford, H., Frank, D., Freschet, G.T., Fyllas, N.M., Gallagher, R.V., Green, W.A., Gutierrez, A.G., Hickler, T., Higgins, S.I., Hodgson, J.G., Jalili, A., Jansen, S., Joly, C.A., Kerkhoff, A.J., Kirkup, D., Kitajima, K., Kleyer, M., Klotz, S., Knops, J.M.H., Kramer, K., Kühn, I., Kurokawa, H., Laughlin, D., Lee, T.D., Leishman, M., Lens, F., Lenz, T., Lewis, S.L., Lloyd, J., Llusià, J., Louault, F., Ma, S., Mahecha, M.D., Manning, P., Massad, T., Medlyn, B.E., Messier, J., Moles, A.T., Müller, S.C., Nadrowski, K., Naeem, S., Niinemets, Ü., Nöllert, S., Nüske, A., Ogaya, R., Oleksyn, J., Onipchenko, V.G., Onoda, Y., Ordoñez, J., Overbeck, G., Ozinga, W.A., Patiño, S., Paula, S., Pausas, J.G., Peñuelas, J., Phillips, O.L., Pillar, V., Poorter, H., Poorter, L., Poschlod, P., Prinzing, A., Proulx, R., Rammig, A., Reinsch, S., Reu, B., Sack, L., Salgado-Negret, B., Sardans, J., Shiodera, S., Shipley, B., Siefert, A., Sosinski, E., Soussana, J.F., Swaine, E., Swenson, N., Thompson, K., Thornton, P., Waldram, M., Weiher, E., White, M., White, S., Wright, S.J., Yguel, B., Zaehle, S., Zanne, A.E., Wirth, C., 2011. TRY - a global database of plant traits. Glob. Chang. Biol. 17, 2905-2935. https://doi.org/10.1111/j.1365-2486.2011.02451.X.

Kearsley, E., Verbeeck, H., Hufkens, K., Van de Perre, F., Doetterl, S., Baert, G., Beeckman, H., Boeckx, P., Huygens, D., 2017. Functional community structure of African monodominant Gilbertiodendron dewevrei forest influenced by local environmental filtering. Ecol. Evol. 7, 295-304

Khasanah, N., van Noordwijk, M., Ningsih, H., Wich, S., 2015. Aboveground carbon stocks in oil palm plantations and the threshold for carbon-neutral vegetation conversion on mineral soils. Cogent Environ. Sci. 1, 1119964. https://doi.org/10.1080/ 23311843.2015.1119964.

Klanderud, K., Mbolatiana, H.Z.H., Vololomboahangy, M.N., Radimbison, M.A., Roger, E., Totland, Ø., Rajeriarison, C., 2009. Recovery of plant species richness and composition after slash-and-burn agriculture in a tropical rainforest in Madagascar. Biodivers. Conserv. 19, 187-204. https://doi.org/10.1007/s10531-009-9714-3.

Koné, A.W., Edoukou, E.F., Gonnety, J.T., N'Dri, A.N.A., Assémien, L.F.E., Angui, P.K.T., Tondoh, J.E., 2012. Can the shrub Chromolaena odorata (Asteraceae) be considered as improving soil biology and plant nutrient availability? Agrofor. Syst. 85, 233-245. https://doi.org/10.1007/s10457-012-9497-5.

Kotto-same, J., Woomer, P.L., Appolinaire, M., Louis, Z., 1997. Carbon dynamics in slashand-bum agriculture and land use alternatives of the humid forest zone in Cameroon. Agric. Ecosyst. Environ. 65, 245-256.

Kupfer, J.A., Webbeking, A.L., Franklin, S.B., 2004. Forest fragmentation affects early successional patterns on shifting cultivation fields near Indian Church, Belize. Agric. Ecosyst. Environ. 103, 509-518. https://doi.org/10.1016/j.agee.2003.11.011.

Laliberte, E., Legendre, P., 2010. A distance-based framework for measuring functional diversity from multiple traits. Ecology 91, 299-305.

Laliberte, E., Legendre, P., Shipley, B., 2014. FD: Measuring Functional Diversity From Multiple Traits, and Other Tools for Functional Ecology. R Package Version 1.0-12.

Lasky, J.R., Uriarte, M., Boukili, V.K., Erickson, D.L., John Kress, W., Chazdon, R.L., 2014. The relationship between tree biodiversity and biomass dynamics changes with tropical forest succession. Ecol. Lett. 17, 1158-1167. https://doi.org/10.1111/ele.12322.

Lawrence, D., 2005. Biomass accumulation after 10-200 years of shifting cultivation in Bornean rain forest. Ecology 86, 26-33.

Lawrence, D., Suma, V., Mogea, J.P., 2005. Change in species composition with repeated shifting cultivation: limited role of soil nutrients. Ecol. Appl. 15, 1952-1967. https:// doi.org/10.1890/04-0841.

Lawrence, D., D'Odorico, P., Diekmann, L., Delonge, M., Das, R., Eaton, J., 2007. Ecological feedbacks following deforestation create the potential for a catastrophic ecosystem shift in tropical dry forest. Proc. Natl. Acad. Sci. U. S. A. 104, 20696-20701. https:// doi.org/10.1073/pnas.0705005104.

Lawrence, D., Radel, C., Tully, K., Schmook, B., Schneider, L., 2010. Untangling a decline in tropical forest resilience: constraints on the sustainability of shifting cultivation across the globe. Biotropica 42, 21-30. https://doi.org/10.1111/j.17447429.2009.00599.x

Lefcheck, J.S., 2015. piecewiseSEM: piecewise structural equation modelling in $\mathrm{r}$ for ecology, evolution, and systematics. Methods Ecol. Evol., 573-579 https://doi.org/ 10.1111/2041-210X.12512.

Lohbeck, M., Poorter, L., Martinez-Ramos, M., Bongers, F., Craft, N.J.B., 2015. Biomass is the main driver of changes in ecosystem process rates during tropical forest succession. Ecology 96, 1242-1252. https://doi.org/10.1890/14-0472.1.sm.

Mason, N.W.H., Mouillot, D., Lee, W.G., Wilson, J.B., 2005. Functional richness, functional and functional evenness divergence: the primary of functional components diversity. Oikos 111, 112-118. https://doi.org/10.1111/j.0030-1299.2005.13886.x.

Molinario, G., 2017. Quantification of land cover and land use within the rural complex of the Democratic Republic of Congo. Environ. Res. Lett. 12, 104001.

Molinario, G., Hansen, M.C., Potapov, P.V., 2015. Forest cover dynamics of shifting cultivation in the Democratic Republic of Congo: a remote sensing-based assessment for 2000-2010. Environ. Res. Lett. 10, 094009. https://doi.org/10.1088/1748-9326/10/9/ 094009.

Moonen, P.C.J., 2017. Integrated Assessment of Options to Reduce Emissions From Deforestation in Tshopo, DR Congo. (PhD Thesis). KU Leuven.

Moonen, P.C.J., Verbist, B., Schaepherders, J., Bwama Meyi, M., Van Rompaey, A., Muys, B., 2016. Actor-based identification of deforestation drivers paves the road to effective REDD+ in DR Congo. Land Use Policy 58, 123-132. https://doi.org/10.1016/j. landusepol.2016.07.019.

Moran, E., Brondizio, E., Tucker, J.M., Silva-Forsberg, M.C., McCrackena, S., Falesid, I., 2000. Effects of soil fertility and land-use on forest succession in Amazonia. For. Ecol. Manag. 139, 93-108. 
Mukul, S.A., Herbohn, J., 2016. The impacts of shifting cultivation on secondary forests dynamics in tropics: a synthesis of the key findings and spatio temporal distribution of research. Environ. Sci. Pol. 55, 167-177. https://doi.org/10.1016/j.envsci.2015.10.005.

Nakagawa, S., Schielzeth, H., 2013. A general and simple method for obtaining R 2 from generalized linear mixed-effects models. Methods Ecol. Evol. 4, 133-142. https:// doi.org/10.1111/j.2041-210x.2012.00261.x.

Ngobo, M., McDonald, M., Weise, S., 2004. Impacts of type of fallow and invasion by Chromolaena odorata on weed communities in crop fields in Cameroon. Ecol. Soc 9

Nolte, C., Moukam, A., Thenkabail, P.S., Weise, S.F., Woomer, P.L., 2001. Land-use Characterization and Estimation of Carbon Stocks in the Alternatives to Slash-and-Burn Benchmark Area in Cameroon.

Norden, N., Angarita, H.A., Bongers, F., Martínez-Ramos, M., Granzow-De La Cerda, I., van Breugel, M., Lebrija-Trejos, E., Meave, J.A., Vandermeer, J., Williamson, G.B., Finegan, B., Mesquita, R., Chazdon, R.L., 2015. Successional dynamics in Neotropical forests are as uncertain as they are predictable. Proc. Natl. Acad. Sci. U. S. A. 112, 8013-8018. https://doi.org/10.1073/pnas.1500403112.

Norgrove, L., Beck, J., 2016. Biodiversity function and resilience in tropical agroforestry systems including shifting cultivation. Curr. For. Rep. 2, 62-80. https://doi.org/ 10.1007/s40725-016-0032-1.

Norgrove, L., Hauser, S., 2015. Estimating the consequences of fire exclusion for food crop production, soil fertility, and fallow recovery in shifting cultivation landscapes in the humid tropics. Environ. Manag. 55, 536-549. https://doi.org/10.1007/s00267-0140431-7.

Norgrove, L., Hauser, S., 2016. Biophysical criteria used by farmers for fallow selection in West and Central Africa. Ecol. Indic. 61, 141-147. https://doi.org/10.1016/j. ecolind.2015.06.013.

Norgrove, L., Hauser, S., Weise, S.F., 2000. Response of Chromolaena odorata to timber tree densities in an agrisilvicultural system in Cameroon: aboveground biomass, residue decomposition and nutrient release. Agric. Ecosyst. Environ. 81, 191-207. https:// doi.org/10.1016/S0167-8809(00)00171-7.

Okangola Ekeli, F.R., 2007. Contribution A L'étude Biologique Et Ecologique Des Chenilles Comestibles De La Région De Kisangani. Cas De Réserve De La Yoko. (Ubundu, République Démocratique Du Congo). (Unpublished Master Thesis). Université de Kisangani, DR Congo.

OSFAC, 2010. Forêts d'Afrique centrale evaluées par télédétection (FACET). Etendue et perte du couvert forestier en République Démocratique du Congo de 2000 à 2010.

Pakeman, R.J., Quested, H.M., 2007. Sampling plant functional traits: what proportion of the species need to be measured? Appl. Veg. Sci. 10, 91-96. https://doi.org/ 10.1111/j.1654-109X.2007.tb00507.x.

Palm, C.A., Swift, M.J., Woomer, P.L., 1996. Soil biological dynamics in slash-and-burn agriculture. Agric. Ecosyst. Environ. 58, 61-74. https://doi.org/10.1016/0167-8809(95) 00653-2.

Palm, C.A., Woomer, P.L., Alegre, J., Arevalo, L., Castilla, C., Cordeiro, D.G., Feigl, B., Hairiah, K., Mendes, A., Moukam, A., Njomgang, R., Parton, W.J., Ricse, A., Rodrigues, V., Sitompul, S.M., 1999. Carbon sequestration and trace gas emissions in slash-andburn and alternative land uses in the humid tropics. ASB Clim. Chang. Work. Gr. 29.

Peel, M.C., Finlayson, B.L., McMahon, T.A., 2007. Updated world map of the Köppen-Geiger climate classification. Hydrol. Earth Syst. Sci. Discuss. 4, 439-473.

Phillips, O., Baker, T., Feldpausch, T.R., Brienen, R., 2016. RAINFOR Field manual for plot establishment and remeasurement. Available at. http://www.rainfor.org/en/manuals/ in-the-field.

Poorter, L., Bongers, F., Aide, T.M., Almeyda Zambrano, A.M., Balvanera, P., Becknell, J.M., Boukili, V., Brancalion, P.H.S., Broadbent, E.N., Chazdon, R.L., Craven, D., de AlmeidaCortez, J.S., Cabral, G.A.L., de Jong, B.H.J., Denslow, J.S., Dent, D.H., DeWalt, S.J., Dupuy, J.M., Durán, S.M., Espírito-Santo, M.M., Fandino, M.C., César, R.G., Hall, J.S., Hernandez-Stefanoni, J.L., Jakovac, C.C., Junqueira, A.B., Kennard, D., Letcher, S.G., Licona, J.-C., Lohbeck, M., Marín-Spiotta, E., Martínez-Ramos, M., Massoca, P. Meave, J.A., Mesquita, R., Mora, F., Muñoz, R., Muscarella, R., Nunes, Y.R.F., OchoaGaona, S., de Oliveira, A.A., Orihuela-Belmonte, E., Peña-Claros, M., Pérez-García, E.A., Piotto, D., Powers, J.S., Rodríguez-Velázquez, J., Romero-Pérez, I.E., Ruíz, J., Saldarriaga, J.G., Sanchez-Azofeifa, A., Schwartz, N.B., Steininger, M.K., Swenson, N.G., Toledo, M., Uriarte, M., van Breugel, M., van der Wal, H., Veloso, M.D.M., Vester, H.F.M., Vicentini, A., Vieira, I.C.G., Bentos, T.V., Williamson, G.B., Rozendaal, D.M.A., 2016. Biomass resilience of Neotropical secondary forests. Nature 530, 211-214. https://doi.org/10.1038/nature16512.

Potapov, P.V., Turubanova, S.A., Hansen, M.C., Adusei, B., Broich, M., Altstatt, A., Mane, L., Justice, C.O., 2012. Quantifying forest cover loss in Democratic Republic of the Congo, 2000-2010, with Landsat ETM+ data. Remote Sens. Environ. 122, 106-116. https://doi.org/10.1016/j.rse.2011.08.027.

Prado-Junior, J.A., Schiavini, I., Vale, V.S., Arantes, C.S., van der Sande, M.T., Lohbeck, M., Poorter, L., 2016. Conservative species drive biomass productivity in tropical dry forests. J. Ecol. 104, 817-827. https://doi.org/10.1111/1365-2745.12543.

Ravindranath, N.H., Ostwald, M., 2008. Carbon Inventory Methods: Handbook for Greenhouse Gas Inventory, Carbon Mitigation and Roundwood Production. Springer Science + Business Media B.V.

RD Congo, 2015. Plan d'investissement REDD+. Available at. http://www.cafi.org/content/dam/cafi/docs/drc-documents/DRC_2015_Plan\%20Investissement\%20National\% 20REDD\%20RDC\%2024\%20Novembre\%202015.pdf.

Reich, P.B., 2014. The world-wide "fast-slow" plant economics spectrum: a traits manifesto. J. Ecol. 102, 275-301. https://doi.org/10.1111/1365-2745.12211.

Reid, J.L., Holl, K.D., Zahawi, R.A., 2015. Seed dispersal limitations shift over time in tropical forest restoration. Ecol. Appl. 25, 1072-1082. https://doi.org/10.1890/14-1399.1.
Reiss, J., Bridle, J.R., Montoya, J.M., Woodward, G., 2009. Emerging horizons in biodiversity and ecosystem functioning research. Trends Ecol. Evol. 24, 505-514.

Ribeiro Filho, A.A., Adams, C., Manfredini, S., Aguilar, R., Neves, W.A., 2015. Dynamics of soil chemical properties in shifting cultivation systems in the tropics: a metaanalysis. Soil Use Manag. 31, 474-482. https://doi.org/10.1111/sum.12224.

Robiglio, V., Sinclair, F., 2011. Maintaining the conservation value of shifting cultivation landscapes requires spatially explicit interventions. Environ. Manag. 48, 289-306. https://doi.org/10.1007/s00267-010-9611-2.

Shipley, B., 2009. Confirmatory path analysis in a generalized multilevel context. Ecology 90, 363-368. https://doi.org/10.1890/08-1034.1.

Shipley, B., 2013. The AIC model selection method applied to path analytic models compared using a d-separation test. Ecology 94, 560-564. https://doi.org/10.1890/120976.1 .

Styger, E., Rakotondramasy, H.M., Pfeffer, M.J., Fernandes, E.C.M., Bates, D.M., 2007. Influence of slash-and-burn farming practices on fallow succession and land degradation in the rainforest region of Madagascar. Agric. Ecosyst. Environ. 119, 257-269. https:/ doi.org/10.1016/j.agee.2006.07.012.

Szott, L.T., Palm, C.A., Buresh, R.J., 1999. Ecosystem fertility and fallow function in the humid and subhumid tropics. Agrofor. Syst. 47, 163-196.

te Beest, M., Esler, K.J., Richardson, D.M., 2014. Linking functional traits to impacts of invasive plant species: a case study. Plant Ecol. 216, 293-305. https://doi.org/10.1007/ s11258-014-0437-5.

Tucker, J., Brondizio, E.S., Morán, E., 1998a. Rates of forest regrowth in Eastern Amazonia: a comparison of Altamira and Bragantina regions. Pará State, Brazil. Interciencia 23, 64-73.

Tucker, J.M., Brondizio, E.S., Moran, E.F., 1998b. Rates of forest regrowth in Eastern Amazonia: a comparison of Altamira and Bragantina regions, Para state, Brazil Interciencia 23, 64-73.

Tyukavina, A., Stehman, S.V., Potapov, P.V., Turubanova, S.A., Baccini, A., Goetz, S.J., Laporte, N.T., Houghton, R.A., Hansen, M.C., 2013. National-scale estimation of gross forest aboveground carbon loss: a case study of the Democratic Republic of the Congo. Environ. Res. Lett. 8, 044039. https://doi.org/10.1088/1748-9326/8/4/044039.

Van Ranst, E., Baert, G., Ngongo, M., Mafuka, P. (Eds.), 2010. Carte pédologique de Yangambi, Yanonge-Yatolema, échelle 1:50.000. UGent, Hogent, UNILU, UNIKIN R.D. Congo. ISBN: 9789491114069.

van Vliet, N., Mertz, O., Heinimann, A., Langanke, T., Pascual, U., Schmook, B., Adams, C., Schmidt-Vogt, D., Messerli, P., Leisz, S., Castella, J.-C., Jørgensen, L., Birch-Thomsen, T., Hett, C., Bech-Bruun, T., Ickowitz, A., Vu, K.C., Yasuyuki, K., Fox, J., Padoch, C. Dressler, W., Ziegler, A.D., 2012. Trends, drivers and impacts of changes in swidden cultivation in tropical forest-agriculture frontiers: a global assessment. Glob. Environ. Chang. 22, 418-429. https://doi.org/10.1016/j.gloenvcha.2011.10.009.

Verbeeck, H., Betehndoh, E., Maes, W.H., Hubau, W., Kearsley, E., Buggenhout, L., Hufkens, K., Huygens, D., Van Acker, J., Beeckman, H., Mweru, J.P.M., Boeckx, P., Steppe, K., 2014. Functional leaf trait diversity of 10 tree species in Congolese secondary tropical forest. J. Trop. For. Sci. 26, 409-419.

Vilà, M., Carrillo-Gavila, A., Vayreda, J., Bugmann, H., Fridman, J., Grodzki, W., Haase, J. Kunstler, G., Schelhaas, M., Trasobares, A., 2013. Disentangling biodiversity and climatic determinants of wood production. PLoS One 8. https://doi.org/10.1371/journal.pone.0053530.

Villéger, S., Mason, N.W.H., Muillot, D., 2008. New multidimensional functional diversity indices for a multifaceted framework in functional ecology. Ecology 89, 2290-2301.

Violle, C., Navas, M.L., Vile, D., Kazakou, E., Fortunel, C., Hummel, I., Garnier, E., 2007. Let the concept of trait be functional! Oikos 116, 882-892. https://doi.org/10.1111/ j.2007.0030-1299.15559.x.

Wadsworth, G., Reisenauer, H.M., Gordon, D.R., Singer, M.J., 1990. Effects of forest fallow on fertility dynamics in a Mexican utisol. Plant Soil 122, 151-156.

Williamson, G.B., Bentos, T.V., Longworth, J.B., Rita, C.G., 2014. Convergence and divergence in alternative successional pathways in Central Amazonia. Plant Ecol. Divers. 7, 341-348. https://doi.org/10.1080/17550874.2012.735714.

Wood, S.L.R., Rhemtulla, J.M., Coomes, O.T., 2017. Cropping history trumps fallow duration in long-term soil and vegetation dynamics of shifting cultivation systems. Ecol. Appl. 27, 519-531. https://doi.org/10.1002/eap.1462.

Worbes, M., Staschel, R., Roloff, A., Junk, W.J., 2003. Tree ring analysis reveals age structure, dynamics and wood production of a natural forest stand in Cameroon. For Ecol. Manag. 173, 105-123. https://doi.org/10.1016/S0378-1127(01)00814-3.

Zanne, A.E., Lopez-Gonzalez, G., Coomes, D.A., Illic, J., Jansen, S., Lewis, S., Miller, R.B., Swenson, N.G., Wiemann, M.C., Chave, J., 2009. Data from: towards a worldwide wood economics spectrum. Dryad Digital Repository.

Zarin, D.J., Harris, N.L., Baccini, A., Aksenov, D., Hansen, M.C., Ramos, C.A., Azevedo, T. Margono, B.A., Alencar, A.C., Gabris, C., Allegretti, A., Potapov, P., Farina, M., Walker W.S., Shevade, V.S., Loboda, T.V., Turubanova, S., Tyukavina, A., 2016. Can carbon emissions from tropical deforestation drop by $50 \%$ in five years? Glob. Chang. Biol. 22, 1336-1347. https://doi.org/10.1111/gcb.13153.

Ziegler, A.D., Phelps, J., Yuen, J.Q., Webb, E.L., Lawrence, D., Fox, J.M., Bruun, T.B., Leisz, S.J Ryan, C.M., Dressler, W., Mertz, O., Pascual, U., Padoch, C., Koh, L.P., 2012. Carbon outcomes of major land-cover transitions in SE Asia: great uncertainties and REDD+ policy implications. Glob. Chang. Biol. 18, 3087-3099. https://doi.org/10.1111/j.13652486.2012.02747.x.

Zuur, A.F., Ieno, E.N., Elphick, C.S., 2010. A protocol for data exploration to avoid common statistical problems. Methods Ecol. Evol. 1, 3-14. https://doi.org/10.1111/j.2041210X.2009.00001.x. 